\title{
Novel experimental approach for the characterisation of Lithium-Ion cells performance in isothermal conditions.
}

\author{
S. Landini ${ }^{\mathrm{a}, *}$, T.S. O’Donovan ${ }^{\mathrm{a}}$ \\ ${ }^{a}$ Heriot-Watt University, School of Engineering and Physical Sciences, Institute of Mechanical, Process and Energy Engineering, \\ Riccarton, EH14 4AS Edinburgh, United Kingdom
}

\begin{abstract}
Lithium-Ion cells performance is sensitive to the cell temperature. Therefore, experimental evidence is needed to identify the optimal cell isothermal condition to be achieved by a Thermal Management System (TMS). Previous studies have experimentally investigated the cells electrical performance under adiabatic or controlled environmental temperature (i.e. isoperibolic) thermal boundary conditions. Notably, however, these conditions do not impose a uniform cell's surface temperature, especially at high discharge rates (DR), or a controlled cooling rate, as a TMS would. This research study proposes a novel experimental test rig replicating an active TMS based on a thermal chamber, forced air convection, a micro wind tunnel, and a control system for testing cells in set isothermal conditions. The test rig is proposed in two cooling configurations (single-sided, double-sided). The double-sided configuration, characterised by a superior heat transfer coefficient of $128 \frac{\mathrm{W}}{\mathrm{m}^{2} \mathrm{~K}}$, guarantees a stable cell average surface temperature, equal to the set value, and a temperature disuniformity lower than $5 \mathrm{~K}$ for DRs of up to $2 \mathrm{C}$ and set temperatures in the range of $0^{\circ} \mathrm{C}-40^{\circ} \mathrm{C}$. Moreover, the electrical, thermal, and electrochemical performance of a pouch cell is investigated at DR and at uniform and constant cell temperatures.

Keywords: Thermal Management System, Li-Ion Cells, Isothermalisation, Heat Generation Rate, Electrochemical Efficiency, Micro-Wind Tunnel
\end{abstract}

\footnotetext{
* Corresponding author

Email address: sl30@hw.ac.uk (S. Landini)
} 


\section{Graphical Abstract}
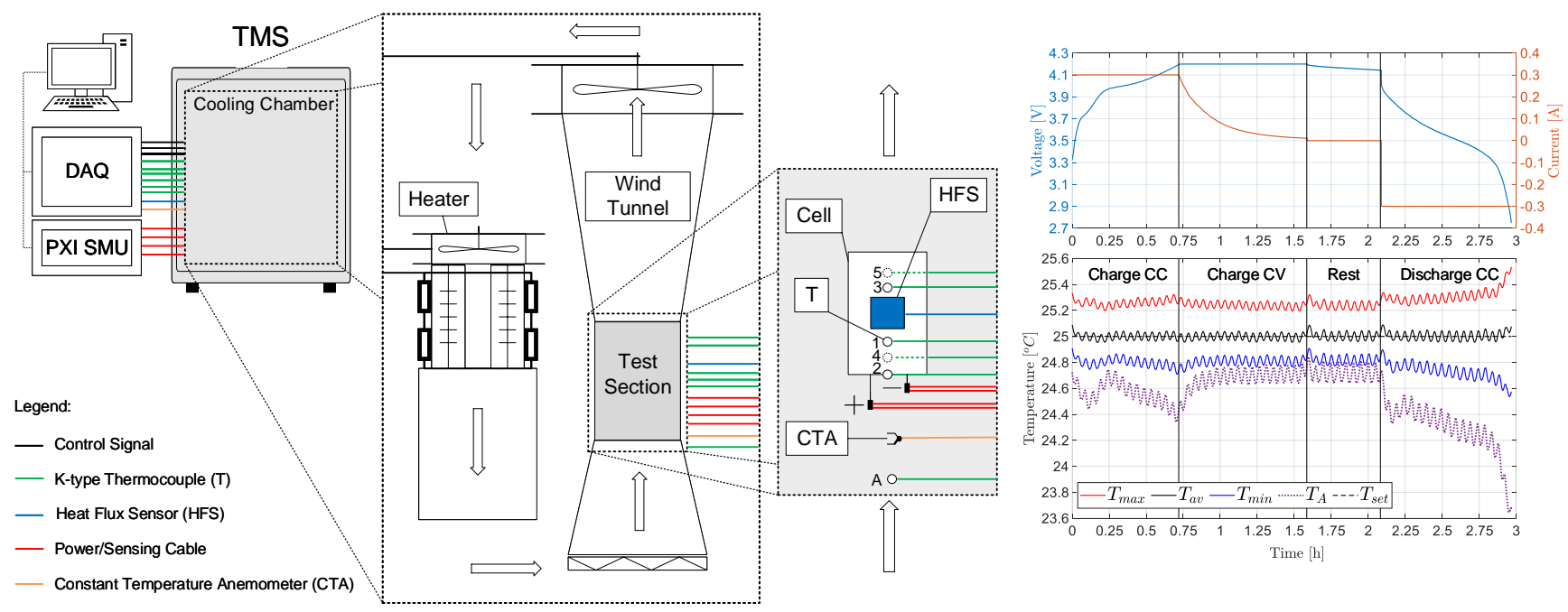


\section{Contents}

Acronyms

Nomenclature

1 Introduction $\quad 6$

2 Methodology $r$

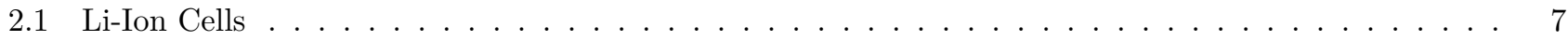

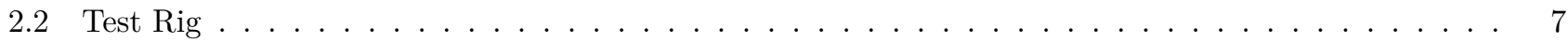

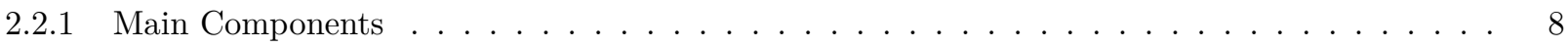

2.2 .2 Thermal Sensors Calibration $\ldots \ldots \ldots \ldots \ldots \ldots$

2.2 .3 Constant Temperature Anemometer Calibration . . . . . . . . . . . . . . . . . . 12

2.3 Test Rig Uncertainty Analysis . . . . . . . . . . . . . . . . . . . . . . . . . . . . . . . . . 13

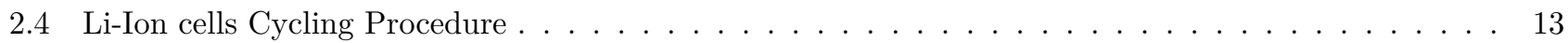

3 Results and Discussions $\quad 14$

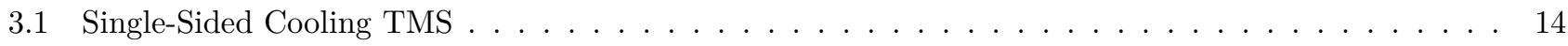

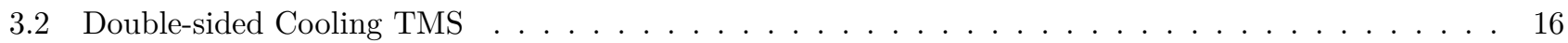

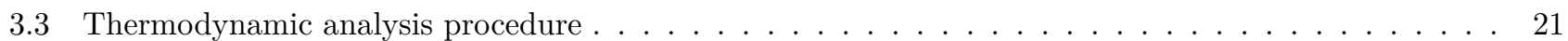

3.4 Li-Ion Cells Electrical, Thermal and Electrochemical Performance . . . . . . . . . . . . . . . . . 22

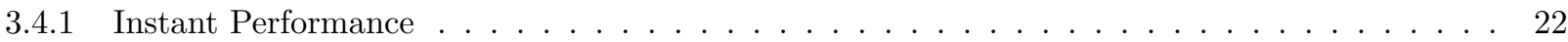

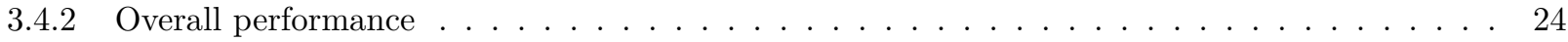

4 Conclusions $r$

5 Acknowledgements 26

6 Data Availability $r$

$\begin{array}{lr}\text { Reference List } & 28\end{array}$ 


\section{Acronyms}

BEV Battery Electric Vehicle 8

BMS Battery Management System 7

CAES Compressed Air Energy Storage 6

CC Constant Current 13, 14, 20

COPs Conference of the Parties 6

CR Charge Rate 13, 14, 20

CTA Constant Temperature Anemometer 8, 12, 13

CV Constant Voltage 13, 14, 20

DAQ Data Acquisition 7, 9, 11

DOD Depth Of Discharge 21-24

DR Discharge Rate 1, 7, 8, 13-27

EESS Electrical Energy Storage System 6

ESS Energy Storage System 6
EV Electric Vehicle 6

HEV Plug-in Hybrid Electric Vehicle 8

HFS Heat Flux Sensor 8, 10-13, 15-17

HR Heat Ratio 14, 21-25

HTF Heat Transfer Fluid 5

MFC Mass Flow Controller 12

PHS Pump Hydro Storage 6

PLA PolyLactic Acid 8

RET Renewable Energy Technologies 6

SMU Power Measure Unit 8, 11, 13, 14, 23

TMS Thermal Management System 1, 3, 6-8, 10, 14, 16-21, 25, 26

VI Virtual Instruments 13 
Nomenclature

\section{Dimensionless Symbols}

$N u_{x} \quad$ Local Nusselt number

$R e_{x} \quad$ Local Reynolds number

Pr Prandtl number

$P e_{x} \quad$ Local Peclet number

\section{Greek Symbols}

$\eta_{I} \quad$ First-law Efficiency

$\mu \quad$ Dynamic Viscosity

$\nu \quad$ Kinematic Viscosity

$\rho \quad$ Density

$\alpha \quad$ Thermal Diffusivity

\section{Roman Symbols}

$c_{p} \quad$ Specific Heat Capacity

$A \quad$ Surface

$k \quad$ Thermal Conductivity

$h \quad$ Specific Enthalphy

m Mass $\dot{m} \quad$ Mass Flow

$p \quad$ Absolute Pressure

$[P a]$

T Temperature

$t \quad$ Time

$\dot{V} \quad$ Volumetric Flow Rate

$\left[\frac{m^{3}}{s}\right]$

V Volume

$\left[m^{3}\right]$

$\dot{Q} \quad$ Heat Flow Rate

$[W]$

$[-]$

$Q \quad$ Heat

$[J]$

$[\mathrm{Pa} \cdot \mathrm{s}]$

$\left[m^{2} \cdot s\right]$

$q \quad$ Heat Flux

$\left[\frac{W}{m^{2}}\right]$

$S \quad$ Entropy

$\left[\frac{J}{K}\right]$

$s \quad$ Specific Entropy

$\left[\frac{J}{k g K}\right]$

\section{Subscript}

$\begin{array}{rll}{\left[\frac{J}{k g K}\right]} & \text { s } & \text { Surface } \\ {\left[m^{2}\right]} & \text { f } & \text { Film } \\ {\left[\frac{W}{m K}\right]} & \text { a } & \text { Ambient } \\ {\left[\frac{J}{k g}\right]} & \text { htf } & \text { HTF } \\ {[k g]} & \text { tot } & \text { Total }\end{array}$




\section{Introduction}

Energy-related $\mathrm{CO}_{2}$ emissions must be lowered if the 187 countries who ratified the Paris Agreement at the $22^{\text {nd }}$ Conference of the Parties COPs [1] are to meet the commitment to keep the global temperature rise within at least $2^{\circ} \mathrm{C}$ of pre-industrial levels and pursue even a better target of $1.5^{\circ} \mathrm{C}[2]$. Renewable energy technologies (RET) and systems can contribute to decarbonise the energy mix [3]. However, renewable energy sources such as wind and solar, even if more predictable compared to the past $[4,5]$, are still inherently intermittent. Therefore, energy storage is essential to match demand with supply [6].

Energy Storage Systems (ESS) are chosen for each application in terms of capacity, discharge period, response time, and power rating for electrical storage, and output temperature and capacity for thermal energy storage [6]. As reported by REN21 [7], the development of electrical RETs is dependent on Electrical Energy Storage Systems EESS which can capture electricity during off-peak or RET overproduction periods and release it during high peak. Also, EESS can be employed for energy arbitrage and demand response [7].

The most developed EESS are Pumped Hydro Storage (PHS), Compressed Air Energy Storage (CAES), and electrochemical cells [8]. These storage technologies serve different storage demands in terms of power $\left(M W_{e}\right.$ for PHS and CAES, $k W_{e}$ for cells) and durations (days/weeks for PHS and CAES, hours for cells) [9].

The global grid-connected storage power by 2018 was $166.6 G W_{e}$, with $96 \%$ being PHS [8]. The advanced (i.e. non-PHS) EESS installed power increased by $12 \%$ compared to 2017 [8]. Interestingly, electrochemical cells (mainly Li-Ion) account for $50 \%$ of the advanced EESS and grew by $43 \%$ compared to 2017 [7]. This steep expansion was mainly attributed to the manufacturing costs decrease by $65 \%$ in the period 2010-2015 driven by the Electric Vehicles (EV) market growth. However, $310 G W_{e}$ additional grid-connected electrical storage power is needed to sustain future decarbonised scenarios [6].

The operating temperature of a Li-Ion cell influences its performance [10]. At low temperatures, cells lose storage, power, energy capacity, and charge acceptability. At high temperatures, their reliability decreases and the risk of thermal runaway rises. Further, extreme temperatures compromise the cell's cycle life. These factors increase the cells' capital, operation and maintenance costs when integrated in an energy system, leading to higher unit price of energy on a full life cycle analysis $[11,12]$.

The effective thermal management of Li-Ion cells, which are exothermic during discharge and subjected to different environmental conditions depending on their application, is therefore essential to reduce the cost of renewable energy $[11,14,13,15]$. The aims of an effective thermal management system (TMS) are twofold: to maintain a battery at an optimal average temperature and minimise temperature disuniformity. This isothermal condition helps to avoid localised cell deterioration and performance reduction $[10,16]$.

Many studies $[17,18,19,20,21,22,23,24,25,26,27,28,29]$ have experimentally investigated the electrical performance of Li-Ion cells under controlled environmental temperatures; notably however, these conditions do not impose a uniform cell surface temperature or a controlled cooling rate, as a TMS would. As it is, the previous literature did not evaluate the sensitivity of the cell performance to the cell temperature but to the ambient 
temperature. Most importantly, by not imposing any specific surface heat flux, cells were typically tested at operating conditions which strongly differ from the ones imposed by a battery management system (BMS).

Previous studies $[17,18,19,20]$ have made contributions in terms of cell electro-thermal characterisation under thermal boundary conditions that were either adiabatic or constant environment temperature, the latter defined as isoperibolic. The current work, however, employs a different approach, as originally proposed in Landini et al. [10], that has specific relevance in many applications, where the battery needs an active TMS. The proposed study characterises the performance of Li-Ion cells under a thermal boundary condition where the surface heat transfer coefficient $h$ is kept constant on the cell and, by dynamically tuning the environment temperature to control the temperature difference between cell and cooling medium, a dynamic surface heat flux is imposed to balance the unstable cell heat generation rate. This guarantees a constant cell surface temperature (not environment temperature) both temporally and spatially. This is crucial, as this is the likely operational scenario for any active cooling approach, as part of a Li-Ion cells TMS. Importantly, this is significantly different from:

1. an adiabatic condition, where the cell body and surface temperature would increase with time [17]

2. a uniform environmental condition (isoperibolic) where the surface temperature and critically the rate of heat transfer from the cell would be significantly different from an active TMS [18, 19, 20]

The current paper does not suggest that previous studies are less relevant, just that the current approach has applications for the bespoke engineering design of TMS specifically for Li-Ion batteries at a cellular level. In addition, a ratio of the heat generation rate to the electrical power, i.e. an equivalent electrochemical efficiency, is proposed here as a metric to advance research in this technological area.

Therefore, this research study proposes a novel experimental apparatus to replicate a TMS based on a thermal chamber, forced air convection, a micro wind tunnel and a control system for testing Li-Ion cells in fixed isothermal conditions. The TMS is proposed in two cooling configurations: single-sided and double-sided. Both TMS configurations ability to maintain isothermal conditions are evaluated throughout a wide range of discharge rates (DR, from $1 \mathrm{C}$ to $5 \mathrm{C}$ ) and temperature settings (from $0^{\circ} \mathrm{C}$ to $40^{\circ} \mathrm{C}$ ). Moreover, electrical, thermal, and electrochemical performance of a Li-ion pouch cell are investigated at different DR and uniform temperatures. Heat generation rate, electrochemical efficiency, and cell surface temperature dis-uniformity are reported.

\section{Methodology}

\subsection{Li-Ion Cells}

The specifics of the Li-Ion cell are reported in Table 1. This cell has been chosen as representative of a common geometry (pouch) and chemistry (cathode $\mathrm{LiCoO}_{2}$, anode graphite, electrolyte $\mathrm{LiPF}_{6}$ ) available commercially. Details are reported in the manufacturer's safety data-sheet [30].

\subsection{Test Rig}

This section identifies the main components of the test rig, including Li-Ion cell cycler, TMS and DAQ. The cycling procedure to charge and discharge a Li-Ion cell is explained. The aim of the test rig is to cycle cells at different DR 
Table 1: Li-Ion cell specifics [30].

\begin{tabular}{l|c}
\hline \hline Component & Li-Ion cell \\
\hline Provider & Reichelt Elektronik \\
Manufacturer & AKKU \\
Application & MP3, iPod Nano 1G \\
Technology & 3.7 \\
Voltage $[\mathrm{V}]$ & 300 \\
Capacity $[\mathrm{mAh}]$ & 32 \\
Length $[\mathrm{mm}]$ & 21 \\
Width $[\mathrm{mm}]$ & 4.8 \\
Height $[\mathrm{mm}]$ & 7 \\
Mass $[\mathrm{g}]$ & 2170 \\
Density $\left[\mathrm{kg} / \mathrm{m}^{3}\right]$ & $1479(1274,1685)$ \\
Specific Heat Capacity* $[\mathrm{J} / \mathrm{kg} \mathrm{K}]$ & ${ }^{*}$ Estimated at Heriot-Watt University \\
\hline \hline
\end{tabular}

(up to 5C) at isothermal conditions (i.e. cell surface temperature stable and uniform) with a target temperature in the range of $0^{\circ} \mathrm{C}-40^{\circ} \mathrm{C}$. DRs in the range of $1 \mathrm{C}-3 \mathrm{C}$ are experienced by cells within battery packed employed in $\mathrm{HEV}$ and BEV [31] while a DR of $5 \mathrm{C}$ was used to test the TMS in an extreme condition.

Along with the cell electrical quantities (i.e. voltage, current, power), heat flux, heat dissipation rate, enthalpy variation, heat generation rate, and electrochemical efficiency are acquired throughout the cycles. A heat flux sensor HFS is used to evaluate the heat transfer coefficient, $h\left[\frac{W}{m^{2} K}\right]$, between the cell surface and the cooling medium. The design and geometry of the test rig guarantees the validity of this unique $h$ throughout the cell surface.

\subsubsection{Main Components}

The main components of the test rig (Figure 1) are reported in Table 2. The cell is positioned on a stand located within the test section (Figure 1) of a micro wind tunnel (Figure 2). The wind tunnel has been 3D-printed by using commercial PLA as it was a cheaper and time-saving manufacturing method compared to metals machining, especially for the test section (Figure 1). Also, PLA is less thermally conductive than metals. This allowed to insulate the cell from the test section and made it exchange heat exclusively with the wind flow, minimising the heat dissipation calculation error.

Five K-type thermocouples and a heat flux sensor (HFS) are applied on the surface of the cell (Figure 3). By measuring surface temperatures and heat flux, heat dissipation rate, enthalpy variation, and heat generation rates can be computed. A constant temperature anemometer (CTA) is positioned at the beginning of the test section (Figure 1) to measure the upstream wind speed. A 4-wire technique is used to measure voltage and current at the cell electrodes by a source measure unit SMU. The extraction fan of the wind tunnel guarantees a stable wind speed of around $20 \mathrm{~m} / \mathrm{s}$ and a consequent stable turbulent forced convection heat transfer regime. The incident wind 
temperature is controlled by activating heating and cooling elements by means of a control system. The cooling element is a commercial refrigeration chamber while the heating element is a heater comprising four $50 \mathrm{~W}$ resistors, finned holder, and a heater fan. All units are connected to a National Instrument DAQ and controlled by LabView software. Sampling rate is fixed to $1 \mathrm{~Hz}$.

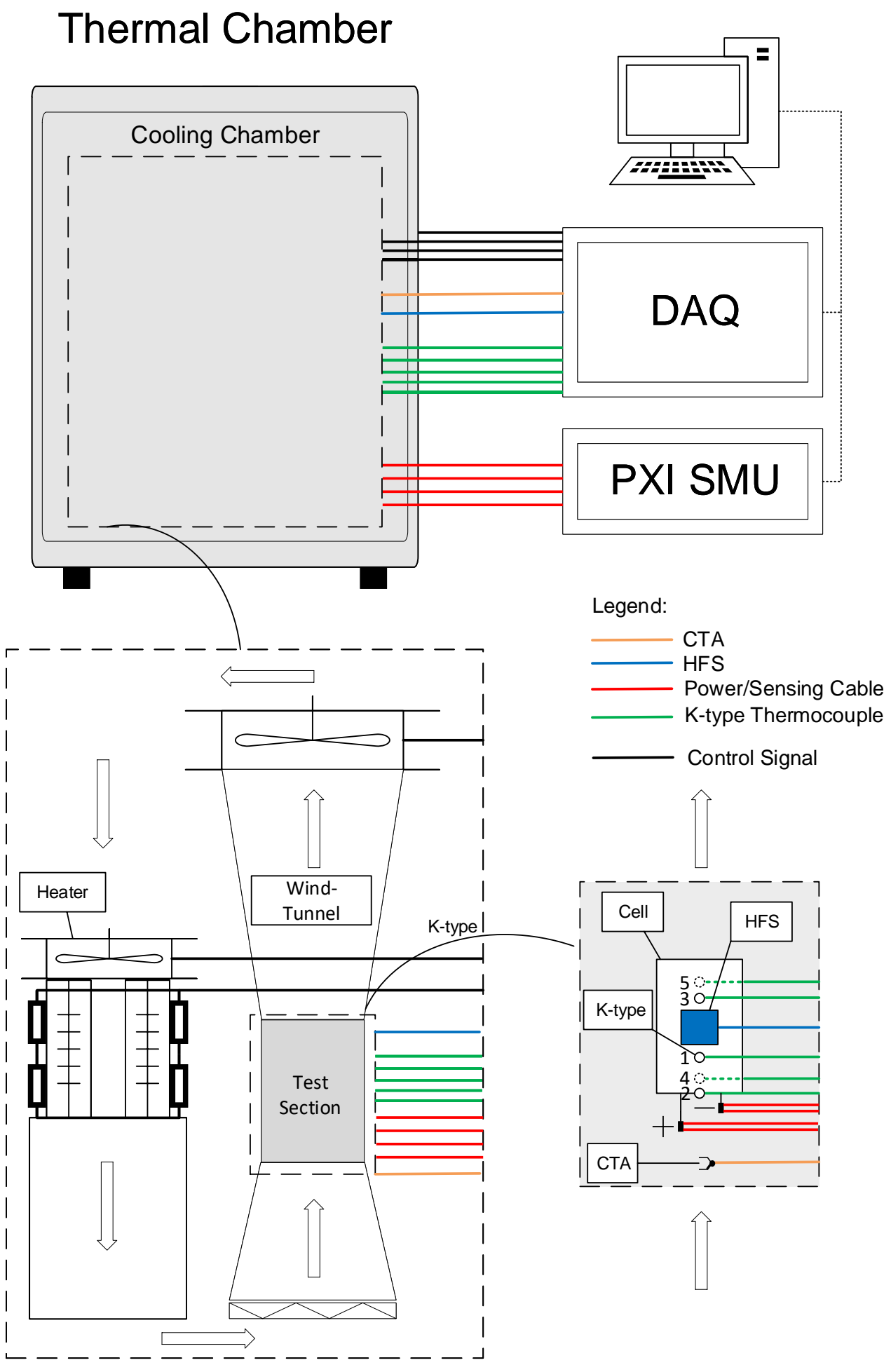

Figure 1: Test rig Overview. 

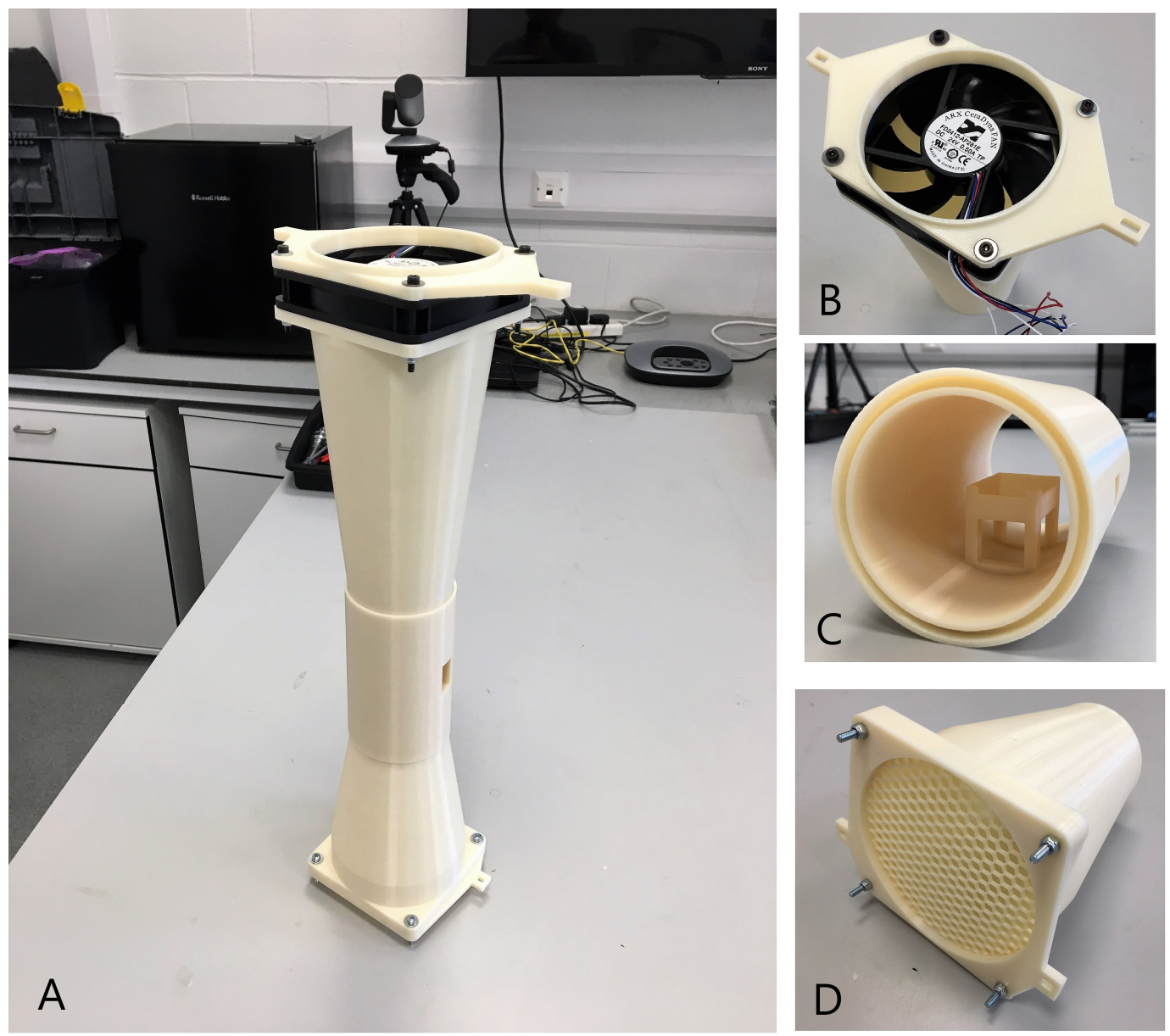

Figure 2: TMS Wind Tunnel (A): diverger with extraction fan (B), cell test section (C), converger with honeycomb filter (D).
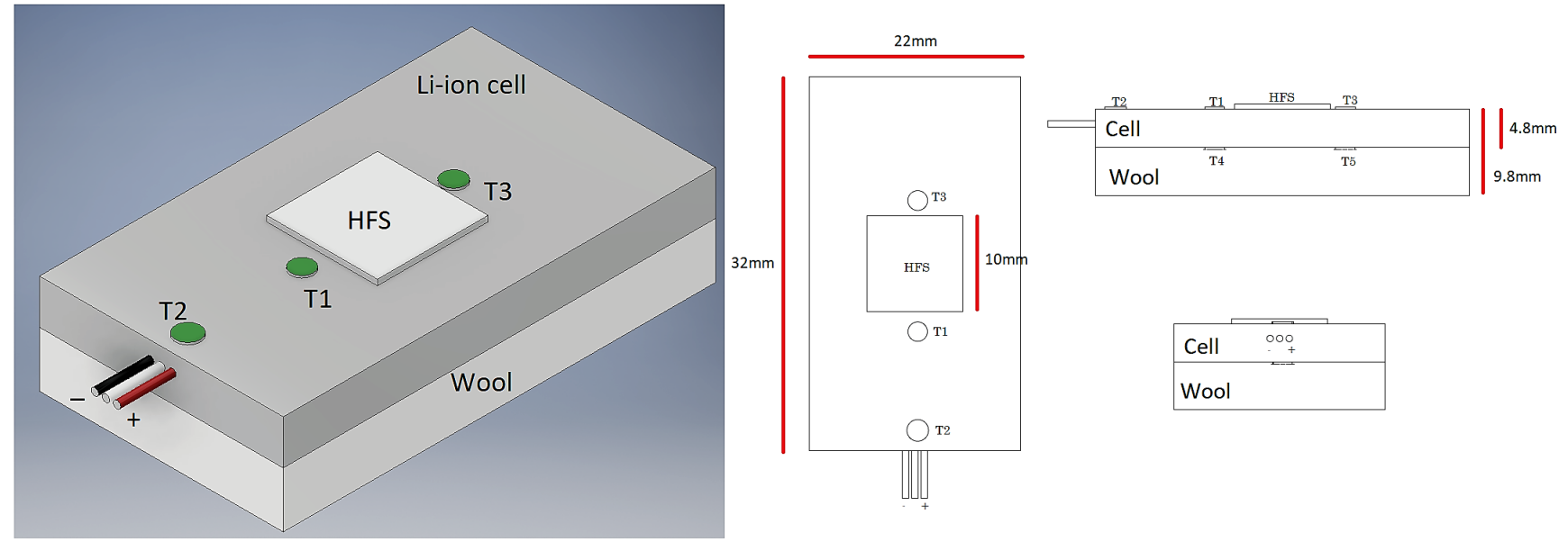

Figure 3: Li-Ion cells TMS: location of thermal sensors (HFS=Heat Flux Sensor, T=Thermocouple). The insulating layer (super-wool) is used exclusively for the single-sided cooling TMS configuration.

\subsubsection{Thermal Sensors Calibration}

A calibration campaign was done following standard procedures [32] on the K-type thermocouples (RS PRO K-type) used in the test rig. A stirred thermostatic bath Grant GD100 was used as temperature reference to calibrate all thermocouples. Data were collected for specific temperature levels $(\mathrm{X})$ in range $20{ }^{\circ} \mathrm{C}-55^{\circ} \mathrm{C}$ with $1{ }^{\circ} \mathrm{C}$ step and 
Table 2: Test Rig Components: Overview

\begin{tabular}{l|l}
\hline \hline Unit & Model \\
\hline Modules Chassis & NI cDAQ-9174 \\
HFS Voltage DAQ & NI-9211 \\
Thermocouples DAQ & NI-9213 \\
SMU Chassis & NI PXI-1033 ExpressCard-8360 \\
SMU & NI PXI-4130 \\
HFS & GreenTeg GSkin-XP-26-9C \\
\hline Thermal Chamber & Indesit OF1A100UK: 250W, Vol 100L \\
Cooling & 4 x ARCOL HS50 2K2 J: 50 W \\
Heating Resistor & Multicomp MCSF23080A/2083HSL.GN: 18W \\
Heating Fan &
\end{tabular}

$55{ }^{\circ} \mathrm{C}-80^{\circ} \mathrm{C}$ with $5{ }^{\circ} \mathrm{C}$ step. The results are reported in Table 3. All temperature measurements are therefore reported within $\pm 0.2^{\circ} \mathrm{C}$ at $95 \%$ confidence.

Table 3: Calibration results for K-type thermocouples (RS PRO K-type): regression analysis of absolute residuals $R=T-T_{r e f}$

\begin{tabular}{l|cccc}
\hline \hline $\mathrm{T}\left[{ }^{\circ} \mathrm{C}\right]$ & $\mathrm{p} 1 *[-]$ & $\mathrm{p} 2 *\left[{ }^{\circ} \mathrm{C}\right]$ & $\mathrm{RMSE}\left[{ }^{\circ} \mathrm{C}\right]$ & $\mathrm{U}^{* *}\left[{ }^{\circ} \mathrm{C}\right]$ \\
\hline $20-80$ & 0.001709 & -0.0978 & 0.0964 & 0.1928 \\
\hline \hline
\end{tabular}

A GreenTeg gSKIN@-XP269C HFS was calibrated by reproducing a force convection on a horizontal iso-heat flux flat plate with a thermally-insulated lower face [34]. A RS Flat Strip Heater 9210035 5"-2" 400W connected to a Power Supply TENMA 728340 was used. The flat plate was located on a stand within a wind tunnel with wind speed capability up to $26 \mathrm{~m} / \mathrm{s}$. The HFS was flush mounted on the heater (Figure 4) using thermal paste to minimise the thermal contact resistance and the other side was insulated by $3 \mathrm{~mm}$ thick layer of insulating wool. Four thermocouples were positioned around the HFS to estimate its temperature (Figure 4). Different wind speeds (up to $13 \mathrm{~m} / \mathrm{s}$ ) and resistor powers (up to $30 \mathrm{~W}$ ) were imposed. Heat flux and temperatures were sampled at steady state condition and the local Reynolds number $\operatorname{Re} e_{x}=\frac{\rho v x}{\mu}$, the Prandtl number $\operatorname{Pr}=\frac{c_{p} \mu}{k}$, the local Nusselt number $N u_{x}=\frac{h_{x} x}{k}$, and the local heat transfer coefficient $h_{x}$ were computed from theoretical correlations (refer to [35]). Then, $h_{x}$ was compared with the $h_{H F S}$ calculated from the heat flux measurements, to compute the relative error $e_{h_{x}}=\frac{h_{H F S}-h_{x}}{h_{H F S}}$. The $e_{h_{x}}$ was analysed for $R e_{x}$ in the range of $4.09 \cdot 10^{3}$ to $6.06 \cdot 10^{4}$, where a $R e_{x}$ of $2 \cdot 10^{4}$ corresponds to the beginning of a fully turbulent regime.

An uncertainty analysis following standard procedures [33] (refer to [35]) on $e_{h_{x}}$ was done to consider the uncertainty introduced by the thermocouples (Table 3$)$ and the wind speed anemometer $(3 \% \pm 0.02 \mathrm{~m} / \mathrm{s})$. Being this uncertainty dependent on the flow regime, laminar and turbulent regimes correlations were considered. The relative uncertainties of $e_{h_{x}}$ for laminar and turbulent regimes were of $1.76 \%$ and $2.03 \%$ respectively. This information was used to 


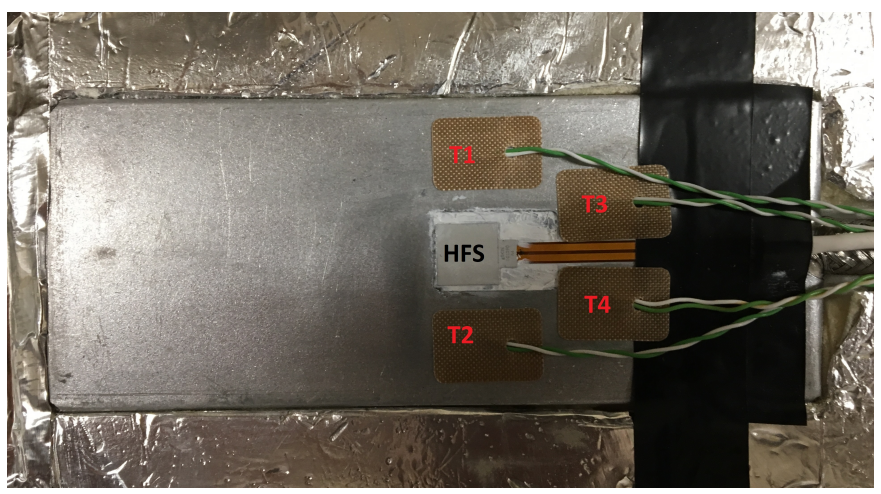

Figure 4: HFS location on the flat heater.

evaluate a $95 \%$ confidence bounds for the relative error $e_{h_{x}}$ for the two flow regimes by adding and subtracting twice the value of $U_{e_{h_{x}}}$. The results are reported for the turbulent regime in the supplementary material [35]. Overall, the HFS had a consistent agreement with turbulent heat flux correlations, with a relative error $e_{h_{x}}$ statistically close to the manufacturer accuracy of $3 \%$. All heat flux measurements are therefore reported within $\pm 3 \%$ at $95 \%$ confidence.

\subsubsection{Constant Temperature Anemometer Calibration}

A constant temperature anemometer CTA sensor dedicated to the measurements of the Li-ion cells upstream air flow speed within the micro wind tunnel was calibrated by using: a Dantec Dynamics Hot-Wire Calibrator (Jet-Flow Simulator and mini-CTA single channel voltage module), a MKS Mass Flow Controller MFC GE50A Air Mass Flow Controller, a NORGREN air flow filter/regulator, a NORGREN pressure gauge 18-015-989, and two RS 363-0250 k-type thermocouples. The CTA sensor (DANTEC Miniature wire probe, straight) was coupled with a NI 9215 voltage module ( $\pm 10 \mathrm{~V}, 16 \mathrm{Bit})$ to measure the voltage across the tungsten filament of the CTA. The calibration curve resembled a typical King's Law $\left(E^{2}=a \cdot v^{b}+c\right)$, where $E$ is the CTA voltage [V], $v$ is the real air jet-flow velocity $[\mathrm{m} / \mathrm{s}]$ and $a, b, c$ are the regression coefficients.

All tests have been done by manually regulating the air main supply valve to guarantee a constant supply pressure of $4 \mathrm{bar}$, read by the pressure gauge. The air flowed through the filter/regulator and entered in the MFC, where its temperatures was measured by the first k-type thermocouple. The MFC digitally controlled the flow rate to a value imposed by the user; response times were typically on the order of 500 milliseconds and accuracies are around $1 \%$. Then, the air was injected in the jet flow calibrator. Here, the jet-flow temperature was also measured by a second k-type thermocouple. The CTA sensor was suspended above the jet-flow nozzle and, by means of the Mini CTA Sensing module, sends a voltage reading (typically in the range of 1-3 V) to the NI 9215 voltage module. Therefore, by tuning the set volumetric flow rate with the MKS MFC from 1,000 up to 50,000 SCCM (Standard Cubic Centimetre per Minute, standard reference $0^{\circ} \mathrm{C}$ and $\left.1 \mathrm{~atm}\right)$ and keeping the main supply pressure constant at 4 bar, it was possible to set different jet-flow velocity from $0.2 \mathrm{~m} / \mathrm{s}$ up to $8 \mathrm{~m} / \mathrm{s}$ and read the CTA voltage signal.

The results lead to a curve in the form of $E^{2}=a \cdot v^{b}+c$, with $\mathrm{a}=0.967, \mathrm{~b}=0.392, \mathrm{c}=1.334$. This law can be rewritten 
as $v=\left(\frac{E^{2}-c}{a}\right)^{\frac{1}{b}}$. The uncertainty analysis on the velocity lead to a calibration curve relative error of $\pm 4.36 \%$. In the range of the Li-ion cells test rig (up to $20 \mathrm{~m} / \mathrm{s}$ ), this leads to a typical uncertainty lower than $0.872 \mathrm{~m} / \mathrm{s}$. For flow temperatures different to the calibration flow temperature $\left(18.82^{\circ} \mathrm{C}\right)$, a correction factor for the voltage of $\left(\frac{T_{\text {wire }}-T_{\text {ref }}}{T_{\text {wire }}-T_{\text {flow }}}\right)^{0.5}$ must be applied on the CTA voltage readings before using the calibration curve.

\subsection{Test Rig Uncertainty Analysis}

Table 4: Test Rig Components: Accuracies and Calibration Range.

\begin{tabular}{l|ccc}
\hline \hline Component & Reading & Accuracy & Range \\
\hline Thermocouple & Temperature & $0.1928^{\circ} \mathrm{C}$ & $20-55{ }^{\circ} \mathrm{C}$ \\
HFS & Heat Flux & $3 \%$ & $R e_{x}=2-6 \cdot 10^{4}$ \\
CTA & Air Speed & $4.36 \%$ & $0-30 \mathrm{~m} / \mathrm{s}$ \\
Scaler & Weight & $0.01 \mathrm{gr}$ & $0-1 \mathrm{~kg}$ \\
Vernier Caliper & Length & $0.01 \mathrm{~mm}$ & $150 \mathrm{~mm}$ \\
SMU & Voltage & $0.03 \%+1.5 \mathrm{mV}$ & $0-6 \mathrm{~V}$ \\
& Current & $0.12 \%+200 \mu \mathrm{A}$ & $0-2 \mathrm{~A}$ \\
\hline \hline
\end{tabular}

All calibration results and accuracies were collected (Table 4) and used to evaluate the uncertainty analysis of the test rig. For the scaler, caliper, and SMU the manufacturer accuracies have been used. The methodology is reported in the supplementary material [35]. Table 5 report the final results with absolute and relative uncertainties. All quantities in the results section are therefore reported within these uncertainties at $95 \%$ confidence.

\subsection{Li-Ion cells Cycling Procedure}

A CC-CV charge method (i.e. Constant Current - Constant Voltage), being the best known technique to charge a Li-Ion cell [36, 37], was implemented using a SMU PXI-4130 commanded by a LabView VI. The same unit can act as a power supply (charge) and as a electronic load (discharge) in a constant current (CC) mode. The overall cycle procedure is reported in Table 6 .

The values of the charge and discharge currents are typically expressed by using two parameters called Charge Rate (CR) and Discharge Rate (DR) which are based on the C-rate. This is defined as the constant current which charges/discharges the entire nominal capacity of the cell in one hour. For instance, a cell of capacity equal to $1 \mathrm{Ah}$ under a $\mathrm{DR}$ of $1 \mathrm{C} / 2 \mathrm{C} / 3 \mathrm{C}$ is operated at a discharge current of $1 \mathrm{~A} / 2 \mathrm{~A} / 3 \mathrm{~A}$.

Figure 5 shows a voltage and current profile for a cycle at $\mathrm{CR}=\mathrm{DR}=1 \mathrm{C}$ and $\mathrm{CV}$ cut-off current of $\mathrm{C} / 30$. The cell is charged first at constant current (CC) until the maximum voltage is reached. Then, the cell is charged at constant voltage $(\mathrm{CV})$ until the current drops below the cut-off current. A period of 30-minute rest follows to cool the cell. Then, a discharge at constant current (CC) is operated until the voltage drops below the minimum voltage. 
Table 5: Uncertainty Test Rig.

\begin{tabular}{l|cccc}
\hline \hline Quantity & Symbol & Unit & $\begin{array}{c}\text { Uncertainty } \\
\text { (absolute) }\end{array}$ & $\begin{array}{c}\text { Uncertainty } \\
\text { (relative) }\end{array}$ \\
\hline Temperature & $\mathrm{T}$ & ${ }^{o} \mathrm{C}$ & 0.1928 & - \\
Temperature Average & $T_{a v}$ & ${ }^{o} \mathrm{C}$ & 0.0862 & - \\
Temperature Difference & $T_{i}-T_{j}$ & ${ }^{o} \mathrm{C}$ & 0.2727 & $5.45 \%$ \\
Temperature Disuniformity & $\Delta T$ & ${ }^{o} \mathrm{C}$ & 0.2727 & $5.45 \%$ \\
Voltage & $\mathrm{V}$ & $\mathrm{mV}$ & 2.76 & $0.0667 \%$ \\
Current & $\mathrm{I}$ & $\mathrm{mA}$ & 2 & $0.13 \%$ \\
Heat Flux & $\mathrm{q}$ & $\frac{W}{m^{2}}$ & 15 & $3 \%$ \\
Specific Heat Capacity & $c_{p}$ & $\frac{J}{k g K}$ & 205 & $13.9 \%$ \\
Heat Transfer Coefficient & $h$ & $\frac{W}{m^{2} K}$ & - & $6.22 \%$ \\
Area & $\mathrm{A}$ & $m^{2}$ & - & $0.29 \%$ \\
Electrical Power & $\mathrm{P}$ & $\mathrm{mW}$ & 9.4 & $0.15 \%$ \\
Heat Dissipation Rate & $\dot{Q}_{l o s s}$ & $\mathrm{~mW}$ & - & $8.28 \%$ \\
Enthalpy Variation & $\frac{\partial H}{\partial t}$ & $\mathrm{~mW}$ & - & $14.9 \%$ \\
Heat Generation Rate & $\dot{Q}$ & $\mathrm{~mW}$ & - & $8.12 \%$ \\
Total Power & $P_{\text {tot }}$ & $\mathrm{mW}$ & - & $0.82 \%$ \\
Electrochemical efficiency & $\eta$ & - & - & $0.83 \%$ \\
HR & $\mathrm{HR}$ & - & - & $8.12 \%$ \\
\hline \hline
\end{tabular}

Table 6: Cell Cycle Procedure

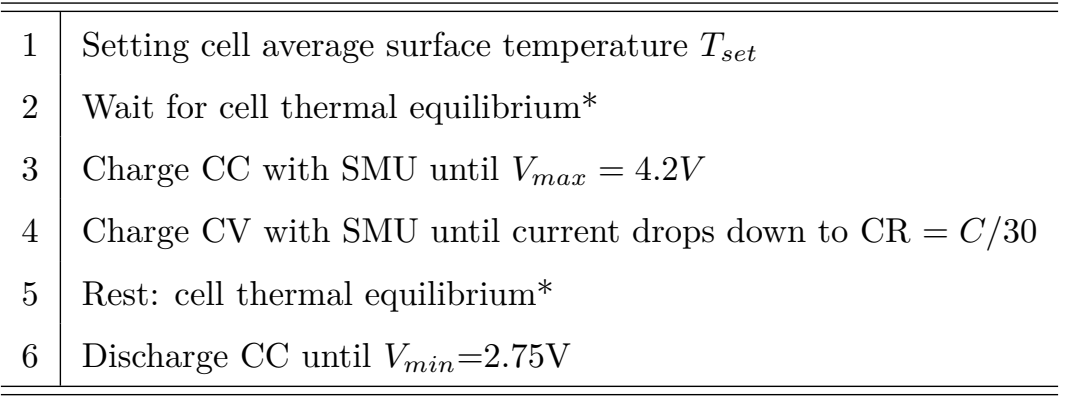

* Average cell temperature $T_{a v}$ in range $\left[T_{\text {set }} \pm 0.1 \mathrm{~K}\right]$ and at least 30 minutes

Heating $\left(T_{a v}<T_{\text {set }}-0.1 \mathrm{~K}\right)$ : resistors and heating fan $\mathrm{ON}$

Cooling $\left(T_{a v}>T_{\text {set }}+0.1 \mathrm{~K}\right)$ : cooling chamber $\mathrm{ON}$

\section{Results and Discussions}

\subsection{Single-Sided Cooling TMS}

This section evaluates the sensitivity of the cell isothermalisation by a single-sided cooling TMS to different DRs and $T_{\text {set }}$. Isothermalisation is a stable cell average surface temperature $T_{a v}$, equal to the set value $T_{\text {set }}$, and a minimum in-cell temperature gradient $\Delta T$ (disuniformity) below $5 \mathrm{~K}[38,39]$ ) 


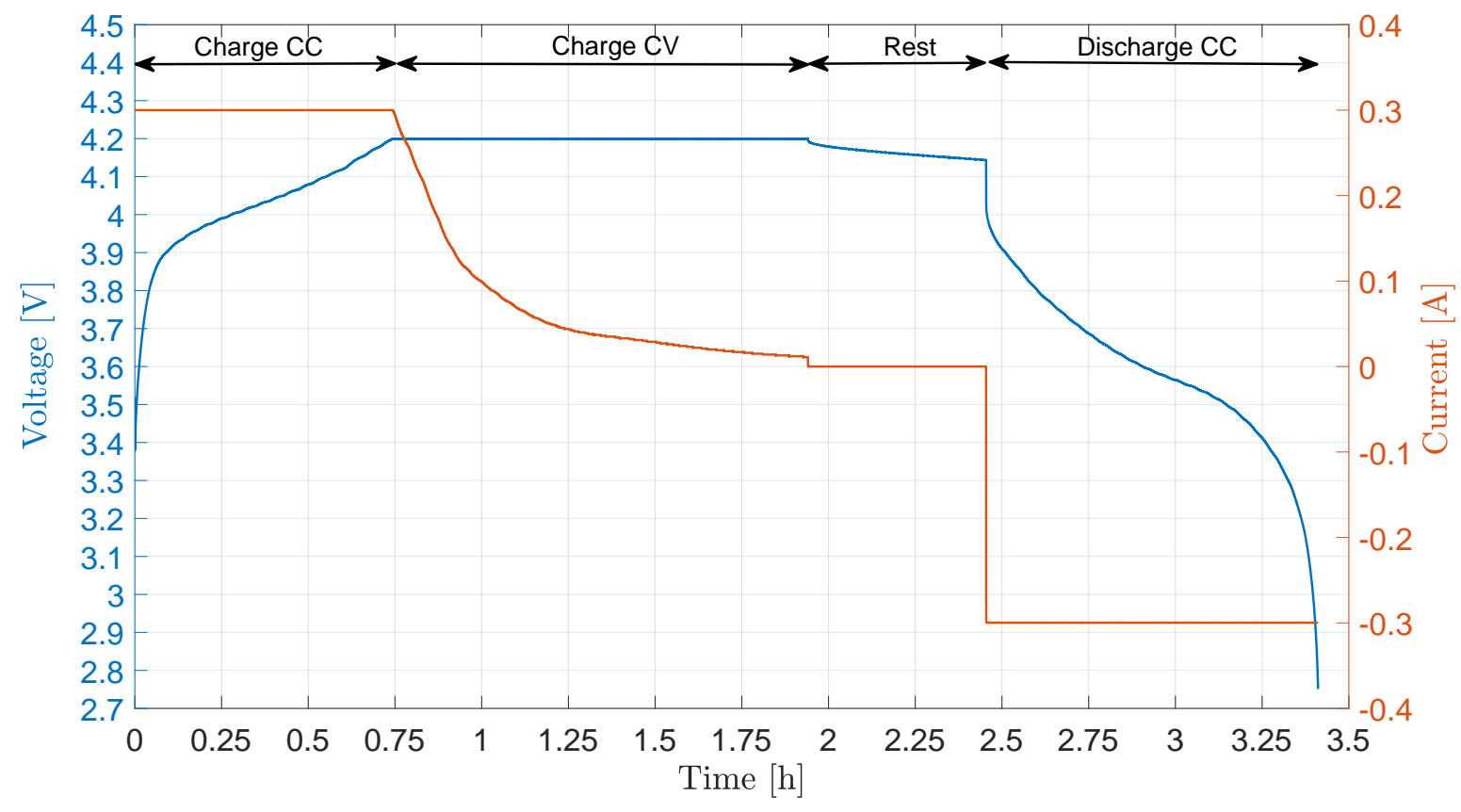

Figure 5: Cycle: voltage and current (positive when charging).

The experimental apparatus is composed of a cooling element, a heating element, and a micro wind tunnel (Figure 1, Figure 2). The wind tunnel guarantees a turbulent forced convection with $R e_{x}>2 \cdot 10^{4}$ on the cell upper surface (Figure 3). Throughout each cycle, by measuring the HFS heat flux (q), HFS temperature $T_{H F S}$ (average of $T_{1}, T_{3}$, Figure 3) and wind temperature $\left(T_{A}\right)$, a heat transfer coefficient $h$ was computed by statistical regression of $q$ vs. $T_{H F S}-T_{A}$ (Figure 6).

Importantly, by guaranteeing a fully turbulent forced convection, with a median free-wind speed, free-stream Re and localised $R e_{x}$ at $25^{\circ} \mathrm{C}$ of $20 \mathrm{~m} / \mathrm{s}, 1.16 \cdot 10^{5}$ and $3.31 \cdot 10^{4}$ respectively, $h$ was independent from the cell surface temperature and therefore valid for the entire surface, unlike for natural convection [40]. This assumption neglects the dependency of $h$ to the distance from the leading edge (x) due to the thermal boundary layer thickness increase. However, the HFS is positioned in the centre of the cell surface and here the $h_{x}$ is measured and assumed equal to average integral $\bar{h}$ [34]. This introduces a negligible error as the average $\bar{h}$, calculated by assuming $N u_{L}=0.037 \cdot \operatorname{Re}_{L}^{0.8} \cdot \operatorname{Pr}^{0.43}[40]$, would be only $5 \%$ different from the $h_{x}$ evaluated at the centre of the cell.

Several cycles have been conducted on the cell for $\mathrm{DR}=1,1.5,2,3,4,5 \mathrm{C}$ and $T_{\text {set }}$ in range $0^{\circ} C-40^{\circ} C$ with step of $5^{\circ} \mathrm{C}$. The overall results are reported in the supplementary material [35]. As shown in Figure 6, the $h_{H F S}$ has been calculated for each test by linear regression of $q_{H F S}$ vs $T_{H F S}-T_{A}$. Overall, $h$ has an average, median, and standard deviation of $86.8 \mathrm{~W} / \mathrm{m}^{2} \mathrm{~K}, 88.4 \mathrm{~W} / \mathrm{m}^{2} \mathrm{~K}$, and $5.3 \mathrm{~W} / \mathrm{m}^{2} \mathrm{~K}$ respectively.

The regressed $h_{H F S}$, being constant and not dependent on $T_{H F S}-T_{A}$, can be used throughout each single test for the calculation of the total heat generation. However, a dependency of $h$ on the absolute $T_{\text {set }}$ is present due to the variation of the air thermo-physical properties as predicted by theoretical correlations. For instance, assuming $N u_{x}=0.032 \cdot \operatorname{Re}_{x}^{0.8} \cdot \operatorname{Pr}^{0.43}[40]$, the standard deviation of the $h_{x}$ with a temperature in the range of $0-40^{\circ} C$ with 
A

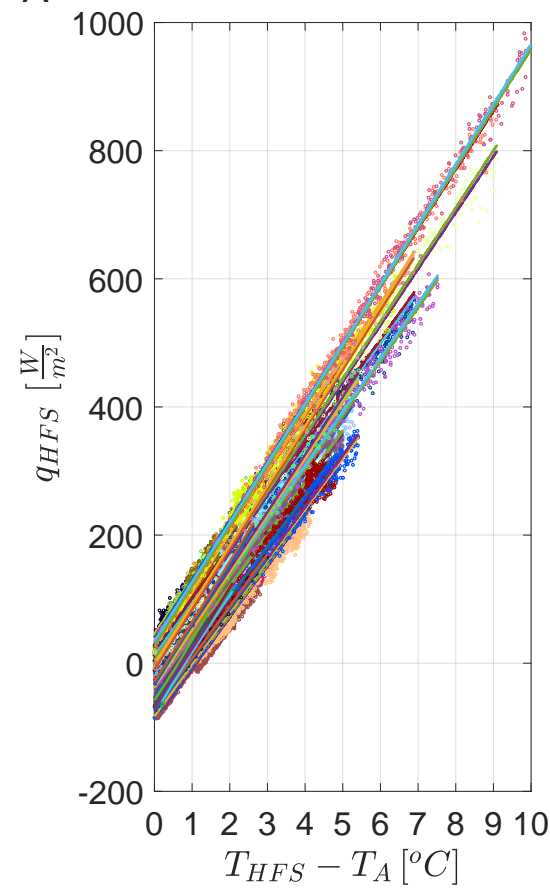

B

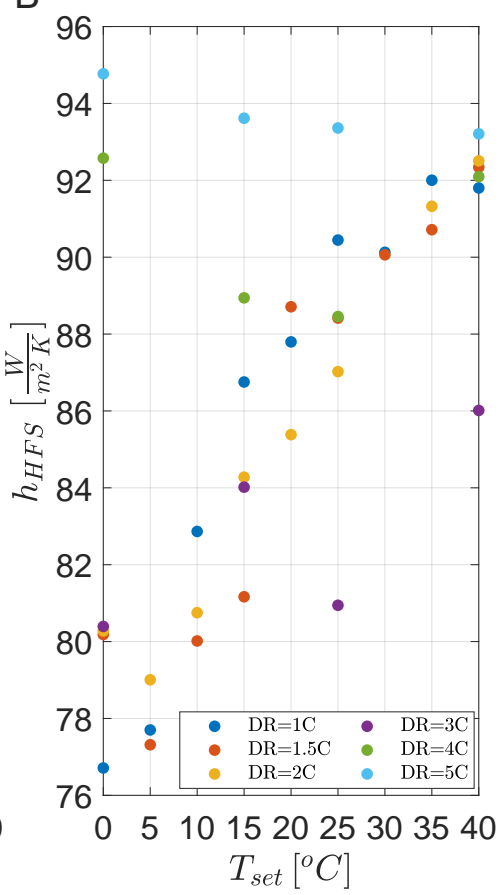

C

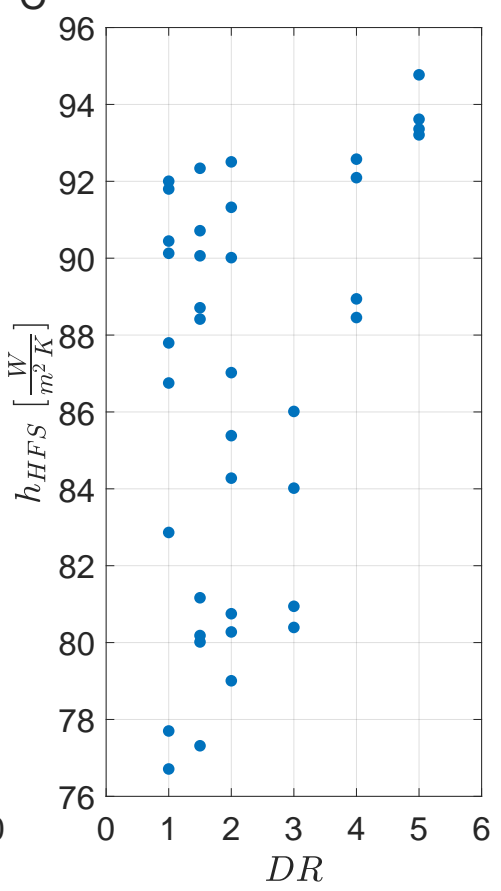

Figure 6: Heat Flux $\left(q_{H F S}, \mathrm{~A}\right)$ and heat transfer coefficient $\left(h_{H F S}\right)$, the latter in function of $T_{\text {set }}(\mathrm{B})$ and DR (C).

wind speed of $20 \mathrm{~m} / \mathrm{s}$ would be $3.05 \frac{W}{m^{2} \mathrm{~K}}$. This is close to the standard deviation of $5.3 \frac{W}{m^{2} \mathrm{~K}}$ experimentally observed (Figure 6, centre).

Figure 7 shows the cell temperature profiles at $\mathrm{DR}=1 \mathrm{C}$ for different set temperatures $\left(T_{\text {set }}\right)$, giving minimum $(\mathrm{A})$, maximum (B), average (C) compared to $T_{\text {set }}$ and the temperature gradient $\Delta T=T_{\max }-T_{\min }(\mathrm{D})$, the latter defined as the difference between maximum and minimum temperatures. The profiles are composed by data sampled at $1 \mathrm{~Hz}$ and reported without piecewise correction. The uncertainty is represented by error bars. Tests conducted at higher DR are reported in the supplementary materials [35].

Overall, the TMS guarantees a constant cell average temperature close to $T_{\text {set }}$ (i.e. the criteria of the control system) when $\mathrm{DR}$ is lower than $3 \mathrm{C}$, even if cell average temperature spikes were observed for $\mathrm{DR}=1.5$ at $T_{\text {set }}=0^{\circ} \mathrm{C}$ and $\mathrm{DR}=2$ at $T_{\text {set }}<20^{\circ} \mathrm{C}[35]$. For all tests, the temperature gradient increases with lower temperatures as the heat generation rate increases, due to a higher cell internal resistance, while the heat transfer coefficient is stable. The temperature gradient is kept below a safe value of $5 \mathrm{~K}$ when $\mathrm{DR}=1 \mathrm{C}$ for all $T_{\text {set }}$. The overall performance are reported in the supplementary materials [35].

\subsection{Double-sided Cooling TMS}

Compared to the previous system, a modified TMS was proposed based on a double-sided cooling implemented within the test section of the micro wind tunnel (Figure 8). This increased the heat transfer coefficient and the heat exchange area, leading to lower in-cell thermal gradients and a better cell thermal regulation.

The cell lower side heat transfer coefficient could be known exactly if an additional HFS was applied locally. However, 


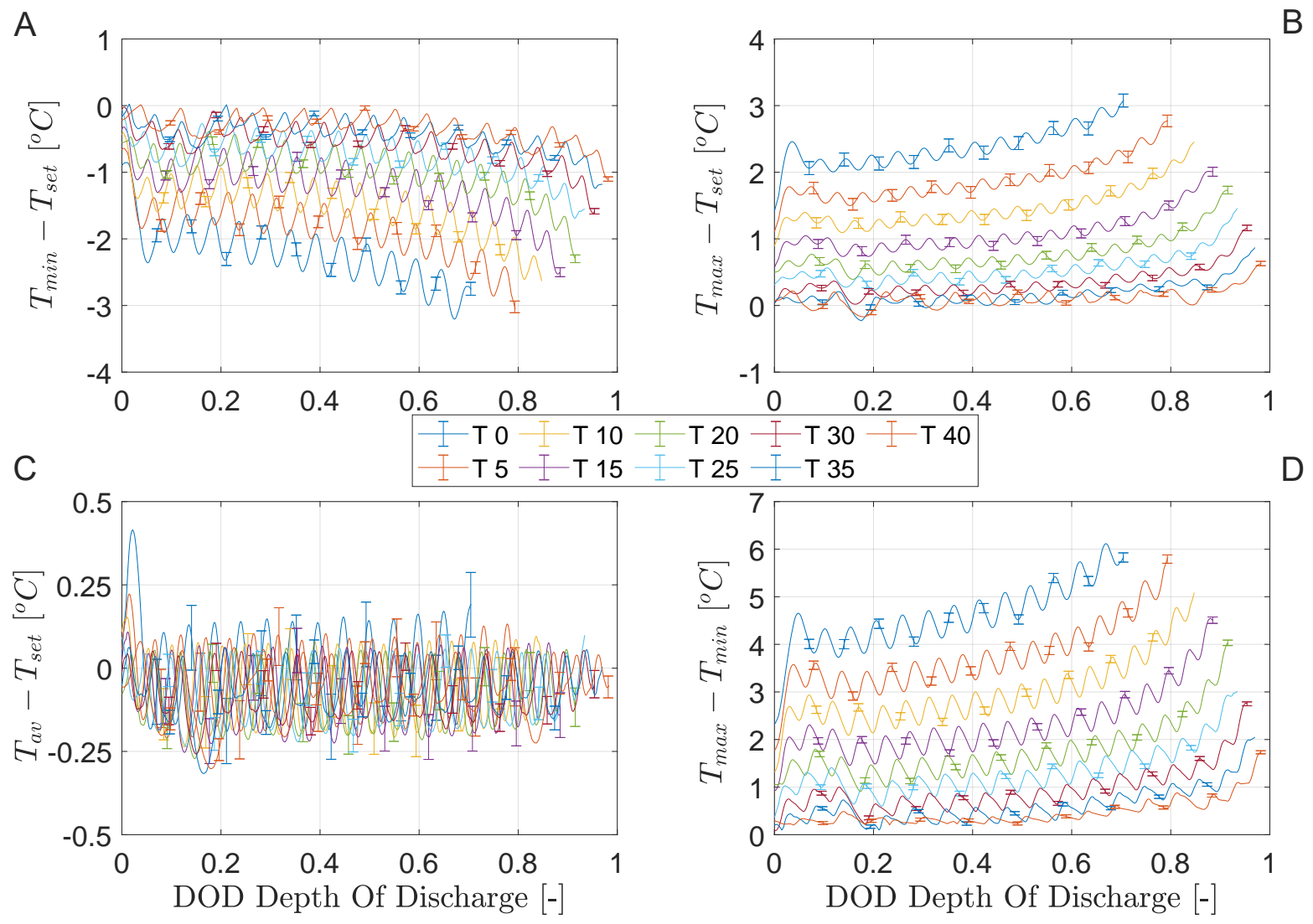

Figure 7: Li-Ion cell temperature profiles at $\mathrm{DR}=1 \mathrm{C}$ for different single-sided cooling TMS set temperatures: minimum (A), maximum (B), average (C), gradient (D).

the modified cell stand was designed to be symmetric in respect to the incoming wind, leading to a symmetric heat transfer regime [34]. This symmetry condition was tested by repeating 200 times a discharge test at $\mathrm{DR}=2 \mathrm{C}$ and $T_{\text {set }}$ of $25^{\circ} \mathrm{C}$. Two identical HFS were positioned on both upper and lower sides of the cell to measure their heat fluxes synchronously. The $h$ was calculated by linear regression of $q$ vs $T_{H F S}-T_{A}$ for both upper $\left(h_{\text {upper }}\right)$ and lower $\left(h_{\text {lower }}\right)$ side. A 2-sample t-test was employed to evaluate the difference between the means at $95 \%$ confidence. The results are reported in Table 7 . While there is strong evidence (p value $<0.001)$ that $h_{\text {upper }}$ and $h_{\text {lower }}$ differ, there is $95 \%$ confidence that this difference is between 11.75 and $16.19 \frac{W}{m^{2} K}$, i.e. less than $10 \%$. Therefore, for the double-side cooling TMS $h_{\text {lower }}$ could be assumed equal to the $h_{\text {upper }}$ and a single HFS on the upper side is applied Figure 3).

As shown in Figure 9, the $h_{H F S}$ has been calculated by linear regression of $q_{H F S}$ vs $T_{H F S}-T_{A}$, with typically $R^{2}$ values greater than $90 \%$. The results show that $h$ has an average, median, and standard deviation of $130 \mathrm{~W} / \mathrm{m}^{2} \mathrm{~K}$, $128 \mathrm{~W} / \mathrm{m}^{2} \mathrm{~K}$ and $9.4 \mathrm{~W} / \mathrm{m}^{2} \mathrm{~K}$ respectively. Moreover, $h_{H F S}$ is independent from the cell surface temperature and DR. Compared to the one-sided TMS (average/median of 86.8/88.4 W/ $\mathrm{m}^{2} \mathrm{~K}$ ), the average/median heat transfer coefficient increased by around 50/44\% and the exchange area doubled.

The results of the TMS tests at $\mathrm{DR}=1 \mathrm{C}$ are reported in Figure 10 for each $T_{\text {set }}$. Tests conducted at higher DR are reported in the supplementary materials [35] together with an evaluation of the performance (mainly the temperature 
Table 7: 2-sample t-test on the heat transfer coefficient mean $\left[\frac{W}{m^{2} K}\right]$ for upper and lower sides of the cell.

\begin{tabular}{c|cc}
\hline \hline Statistics & Upper Side & Lower Side \\
\hline Samples & 200 & 200 \\
Mean & 167.62 & 153.65 \\
$95 \%$ Confidence Range & $(165.9,169.3)$ & $(152.2,155.1)$ \\
Standard Deviation & 12.7 & 10.5 \\
\hline \hline Statistics & Absolute & Relative \\
\hline Mean Difference & 13.97 & $8.3 \%$ \\
$95 \%$ Confidence Range & $(11.75,16.19)$ & $(7 \%, 9.7 \%)$ \\
\hline \hline
\end{tabular}

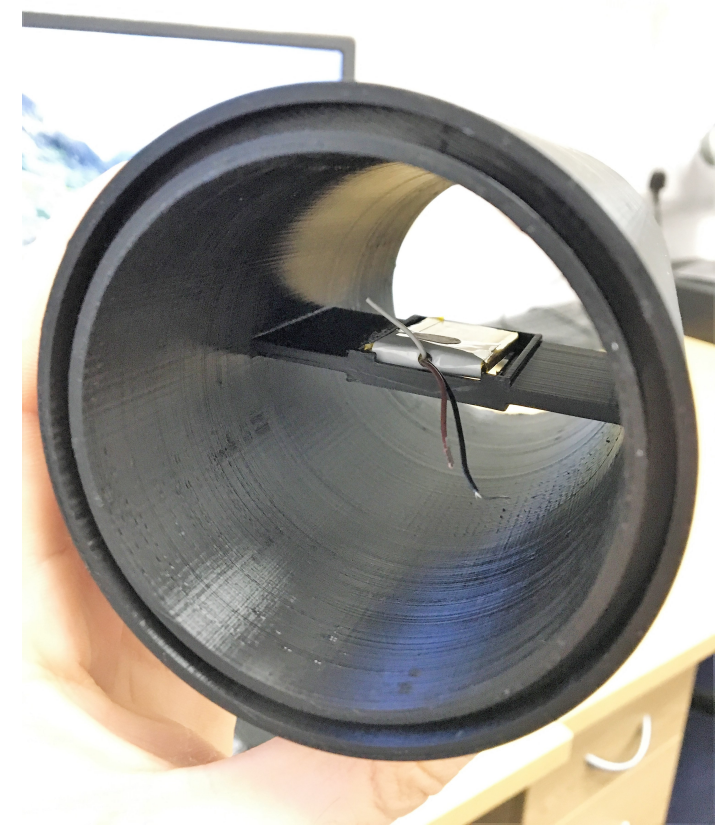

Figure 8: Double-side cooling TMS symmetric test section. Compared to the TMS (Figure 2), both upper and lower side of the cell are exposed to forced convection cooling.

gradient) of this system compared to the previous one.

The double-sided TMS leads to an average/median decrease of the maximum (99\% quantile) in-cell temperature gradient ( $\Delta T^{Q_{99}}$, refer to the supplementary material [35]) of $55 / 66 \%$. This is indeed an improvement towards the cell isothermalisation goal by means of the TMS. Moreover, compared to the previous system, the double-sided cooling TMS can thermally manage a discharge regime of $\mathrm{DR}=2 \mathrm{C}$, having a maximum gradient $\Delta T^{Q_{99}}$ in the worst case scenario $\left(T_{\text {set }}=0^{\circ} \mathrm{C}\right)$ of $4^{\circ} \mathrm{C}$. However, $\mathrm{DR}=1 \mathrm{C}$ still remains a better discharge condition, leading in the worst case scenario $\left(T_{\text {set }}=0^{\circ} \mathrm{C}\right)$ to a temperature gradient lower than $3.5^{\circ} \mathrm{C}$. The overall performance are reported in the supplementary materials [35]. 

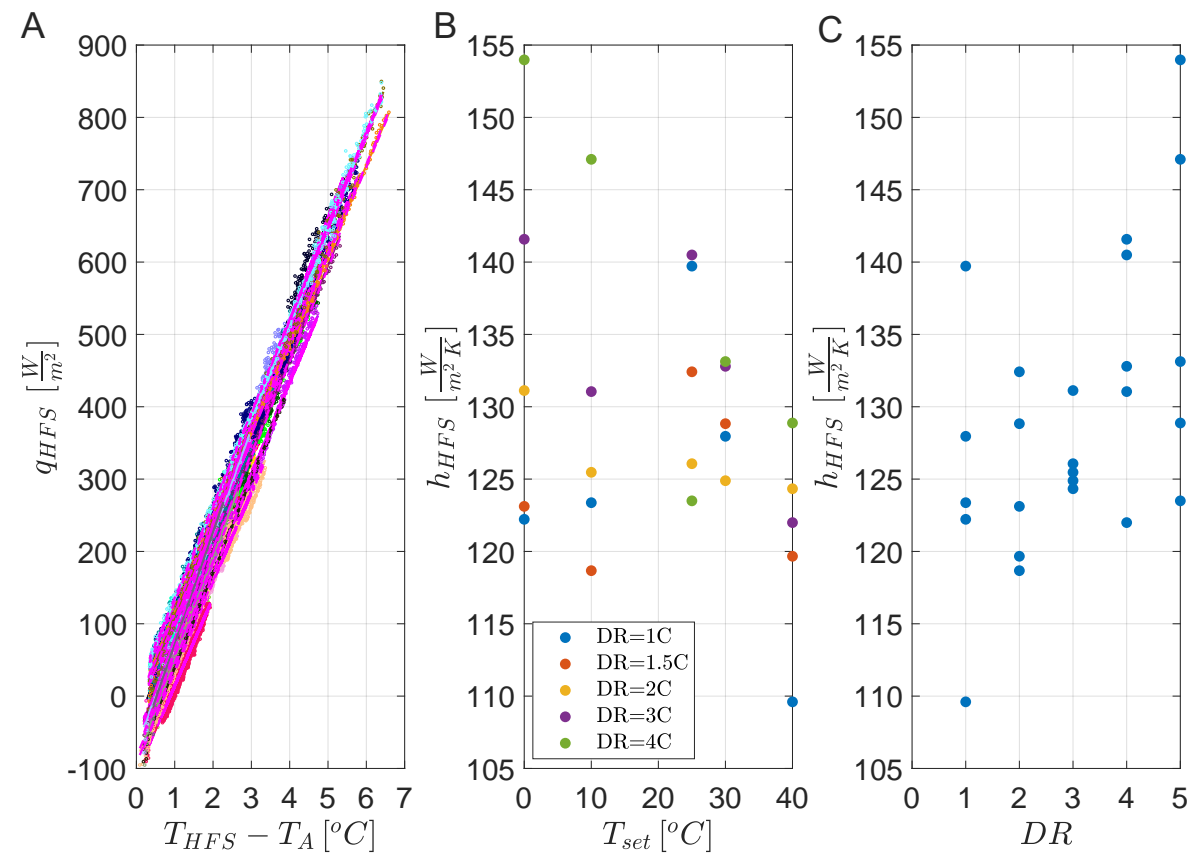

Figure 9: Heat Flux $\left(q_{H F S}, \mathrm{~A}\right)$ and heat transfer coefficient $\left(h_{H F S}\right)$, the latter in function of set temperature (B) and DR (C).

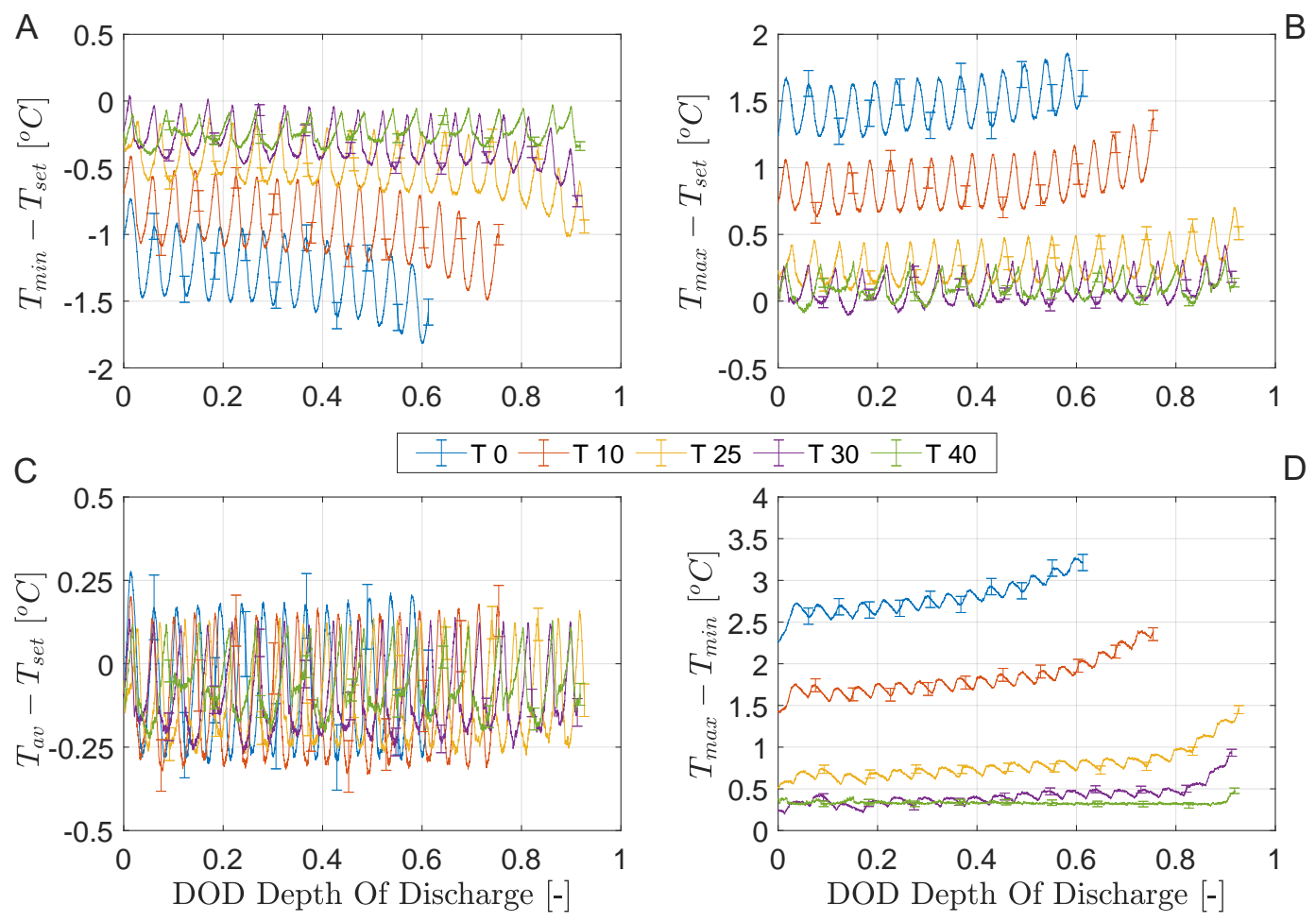

Figure 10: Li-Ion cell temperature profiles at $\mathrm{DR}=1 \mathrm{C}$ for different double-sided cooling TMS set temperatures: minimum (A), maximum (B), average (C) distance from $T_{\text {set }}$, gradient (D).

Overall, the double-sided cooling TMS results in better isothermalisation compared to single-sided cooling TMS. Isothermalised tests at $\mathrm{DR}=2 \mathrm{C}$ for all $T_{\text {set }}$ range evaluated $\left(0^{\circ} \mathrm{C}-40^{\circ} \mathrm{C}\right)$ are possible. Therefore, the results reported in the following sections, unless otherwise stated, are based on the experimental data collected with the upgraded double-sided cooling TMS test rig. 

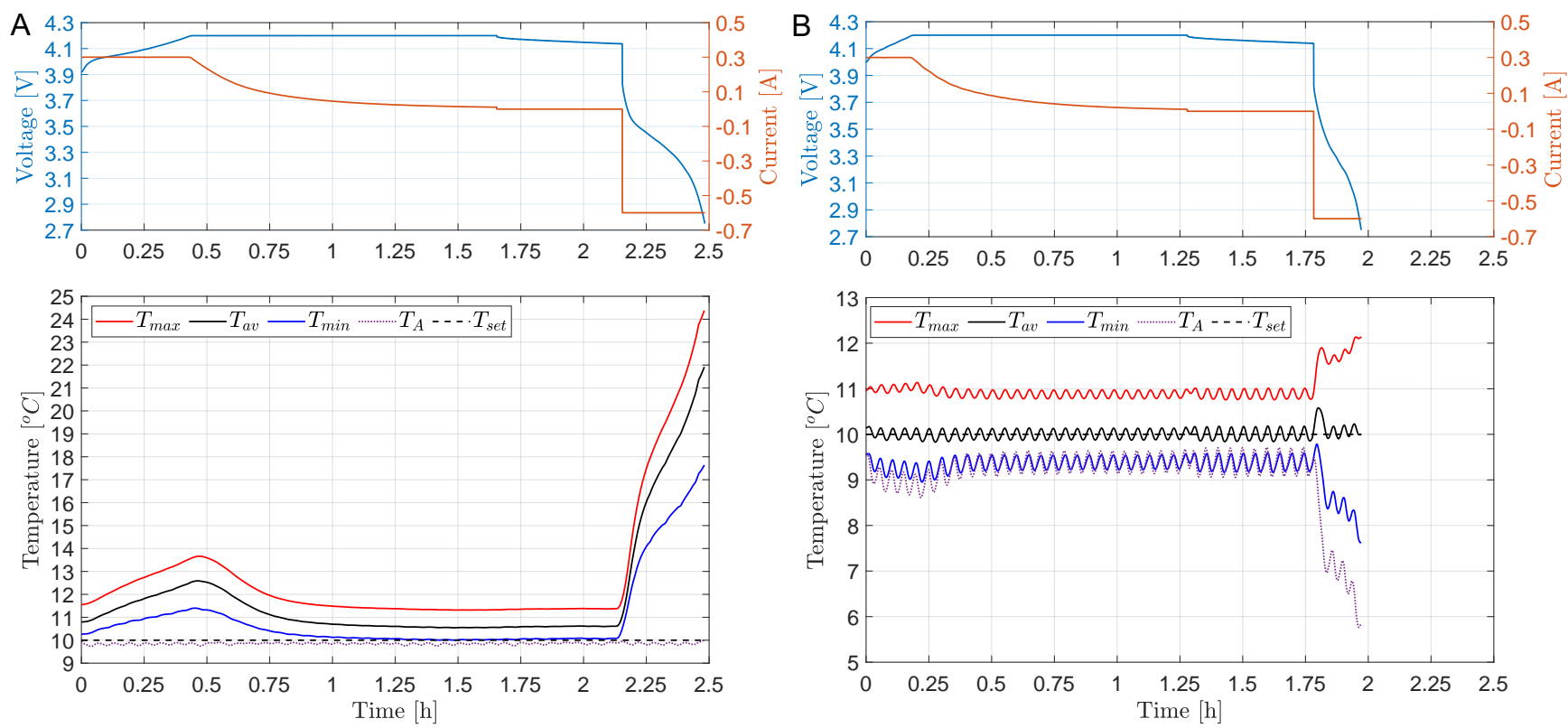

Figure 11: Li-Ion cell surface temperature profiles under a CCCV cycle at $\mathrm{CR}=1 \mathrm{C}$ and $\mathrm{DR}=2 \mathrm{C}$ at: $\mathrm{A}$ ) constant thermal chamber temperature of $10^{\circ} \mathrm{C}$, i.e. isoperibolic condition, B) constant cell average surface temperature of $10^{\circ} \mathrm{C}$, i.e. isothermal condition imposed by the double-sided cooling TMS.

In addition, to evaluate the isothermalisation capability of the novel double-sided cooling TMS compared to a typical isoperibolic thermal boundary condition imposed by thermal chambers or calorimeters as in previous literature $[18,19,20,21,22,23,24,25,26,27,28,29]$, the cell surface temperature profiles under a cycle comprehending a $\mathrm{CCCV}$ charge at $\mathrm{CR}=1 \mathrm{C}$, a 30 -minute rest, and a $\mathrm{CC}$ discharge at $\mathrm{DR}=2 \mathrm{C}$ are reported in Figure 11 and Table 8 for two cases:

A) constant thermal chamber temperature of $10^{\circ} \mathrm{C}$, i.e. isoperibolic condition

B) constant cell average surface temperature of $10^{\circ} \mathrm{C}$, i.e. isothermal condition imposed by the double-sided cooling TMS.

It is clear how imposing an isoperibolic thermal boundary condition (A in Figure 11 and Table 8) and a truly isothermal boundary condition (B in Figure 11 and Table 8) on the cell surface differ. Due to the effect of self-heating, the cell under isoperibolic boundary condition (A) increases its average surface temperature and temperature disuniformity during the discharge phase, leading to performance quantitatively different from a cell under isothermal condition (B), where the self-heating effect is annihilated.

Therefore, the novel approach proposed in this study can guarantee a truly isothermal condition and should be employed in future studies if parametric analyses on the cell performance and ageing tests must be done at the same cell average temperature. The current approach based on an isoperibolic thermal boundary condition using thermal chambers or calorimeters, which do not control the cell surface temperature by imposing a controllable heat flux, leads to an inevitable interdependence between $\mathrm{CR}$, DR, and temperature therefore prohibiting analysis under separation of parameters. Moreover, studies from different authors, even if carried out at an identical thermal chamber or calorimeter temperature (i.e. isoperibolic condition), cannot be truly compared as the cells were inevitably tested at 
different cell temperature, especially at high DR.

Table 8: Li-Ion cell performance under a $\mathrm{CC}$ discharge at $\mathrm{DR}=2 \mathrm{C}$ at: A) constant thermal chamber temperature of $10^{\circ} \mathrm{C}$, i.e. isoperibolic condition, B) constant cell average surface temperature of $10^{\circ} \mathrm{C}$, i.e. isothermal condition imposed by the double-sided cooling TMS.

\begin{tabular}{c|cccccccccccccc}
\hline \hline Test & $\mathrm{BC}$ & $\Delta t$ & $T_{A, a v}$ & $T_{a v}$ & $T_{\max }$ & $\mathrm{DOD}$ & $\mathrm{Cap}$ & $\mathrm{E}$ & $P_{a v}$ & $\mathrm{Q}$ & $\dot{Q}_{a v}$ & $h$ & $\eta$ & $\mathrm{HR}$ \\
\hline $\mathrm{A}$ & Isoperibolic & 1184 & 9.95 & 22.61 & 25.29 & $66 \%$ & 197 & 654 & 1989 & 97 & 295 & 17.9 & $87 \%$ & $15 \%$ \\
$\mathrm{~B}$ & Isothermal & 682 & 6.87 & 10.02 & 12.14 & $38 \%$ & 114 & 372 & 1965 & 78 & 409 & 190.2 & $83 \%$ & $21 \%$ \\
\hline \hline
\end{tabular}

$\mathrm{BC}=$ Boundary Condition, $\Delta t[\mathrm{~s}]=$ period, $T_{A, a v}\left[{ }^{\circ} C\right]=$ average ambient temperature

$T_{a v}\left[{ }^{\circ} \mathrm{C}\right]=$ average cell temperature, $T_{\max }\left[{ }^{\circ} \mathrm{C}\right]=$ maximum cell temperature,

Cap $[\mathrm{mAh}]=$ capacity, $\mathrm{E}[\mathrm{mWh}]=$ energy, $P_{a v}[\mathrm{~mW}]=$ average power

$\mathrm{Q}[\mathrm{mWh}]=$ heat dissipation, $\dot{Q}_{a v}[\mathrm{~mW}]=$ average heat dissipation rate, $h\left[W / m^{2} K\right]$,

$\eta=$ electrochemical efficiency, $\mathrm{HR}=$ heat ratio

\subsection{Thermodynamic analysis procedure}

Once the heat transfer coefficient $h$ is evaluated and assumed uniform on the cell surface, the total heat generation rate $\dot{Q}$ can be computed. As reported in Equation 1 and Equation 2, $\dot{Q}$ is equal to the sum of the heat dissipation $\dot{Q}_{l o s s}$ and the enthalpy variation $\frac{\partial H}{\partial t}$ of all cell sections (5 in these study, see Figure 3). An explicit method as time discretisation numerical technique [41] is used as shown in Equation 2, where $k$ represents the time step (function of the $1 \mathrm{~Hz}$ sampling rate).

$$
\begin{gathered}
\dot{Q}=\left.\sum_{i=1}^{n} \dot{Q}_{i}\right|_{n=5} \\
\dot{Q}_{i}=\dot{Q}_{\text {loss }, i}+\frac{\partial H_{i}}{\partial t} \\
\dot{Q}_{\text {loss }, i}=h \cdot A_{i} \cdot\left(T_{i}-T_{a}\right) \\
\frac{\partial H_{i}}{\partial t}=m_{i} \cdot c_{p}(T) \cdot \frac{\partial T_{i}}{\partial t} \\
\dot{Q}^{k}=\left.\sum_{i=1}^{n} \dot{Q}_{i}^{k}\right|_{n=5} \\
\dot{Q}_{i}^{k}=\dot{Q}_{\text {loss }, i}^{k}+\frac{\partial H_{i}^{k}}{\partial t} \\
\dot{Q}_{\text {loss }, i}^{k}=h \cdot A_{i} \cdot\left(T_{i}^{k-1}-T_{a}^{k-1}\right) \\
\frac{\partial H_{i}^{k}}{\partial t}=m_{i} \cdot c_{p}\left(T_{i}^{k-1}\right) \cdot \frac{T_{i}^{k}-T_{i}^{k-1}}{\Delta t}
\end{gathered}
$$

Once the heat generation rate $\dot{Q}$ is calculated, the electrochemical efficiency $\eta$ and heat ratio HR can be computed as shown in Equation 3:

$$
\begin{aligned}
\eta & =\frac{P}{P+\dot{Q}}=\frac{1}{1+H R}=\frac{P}{P_{t o t}} \\
H R & =\frac{\dot{Q}}{P}=\frac{1-\eta}{\eta}
\end{aligned}
$$


where $\mathrm{P}[\mathrm{W}]$ is the electrical power, $\dot{Q}[\mathrm{~W}]$ is the heat generation rate calculated by Equation $1, P_{t o t}[\mathrm{~W}]$ is the total chemical power discharged by the battery (defined as $P_{t o t}=P+\dot{Q}$ ), $\eta$ is the battery electrochemical efficiency and HR is the heat ratio. These two parameters are instantly determined (i.e. based on power), i.e. for each operating condition (DR, ambient temperature) and specific DOD.

The equivalent total discharge performance (i.e. based on energy) can be evaluated by the overall factors determined by Equation 4:

$$
\begin{aligned}
\eta_{\text {overall }} & =\frac{E}{E+Q}=\frac{1}{1+H R_{\text {overall }}}=\frac{E}{E_{\text {tot }}}=\frac{P_{a v}}{P_{a v}+\dot{Q}_{a v}} \\
H R_{\text {overall }} & =\frac{Q}{E}=\frac{1-\eta_{\text {overall }}}{\eta_{\text {overall }}}=\frac{\dot{Q}_{a v}}{P_{a v}} \\
E & =\int_{t=0}^{t=\tau} P(t) d t, \quad Q=\int_{t=0}^{t=\tau} \dot{Q}(t) d t, \quad \tau=\frac{1}{D R} \\
P_{a v} & =\frac{E}{\tau}, \dot{Q}_{a v}=\frac{Q}{\tau}
\end{aligned}
$$

where $E[\mathrm{Wh}]$ is the total electrical energy discharged, Q $[\mathrm{Wh}]$ is the total heat generated, $P_{a v}[\mathrm{~W}]$ is the average electrical power, $\dot{Q}_{a v}[\mathrm{~W}]$ is the average heat generation rate, $\eta_{\text {overall }}$ is the overall electrochemical efficiency and $H R_{\text {overall }}$ is the overall heat ratio.

\subsection{Li-Ion Cells Electrical, Thermal and Electrochemical Performance}

\subsubsection{Instant Performance}
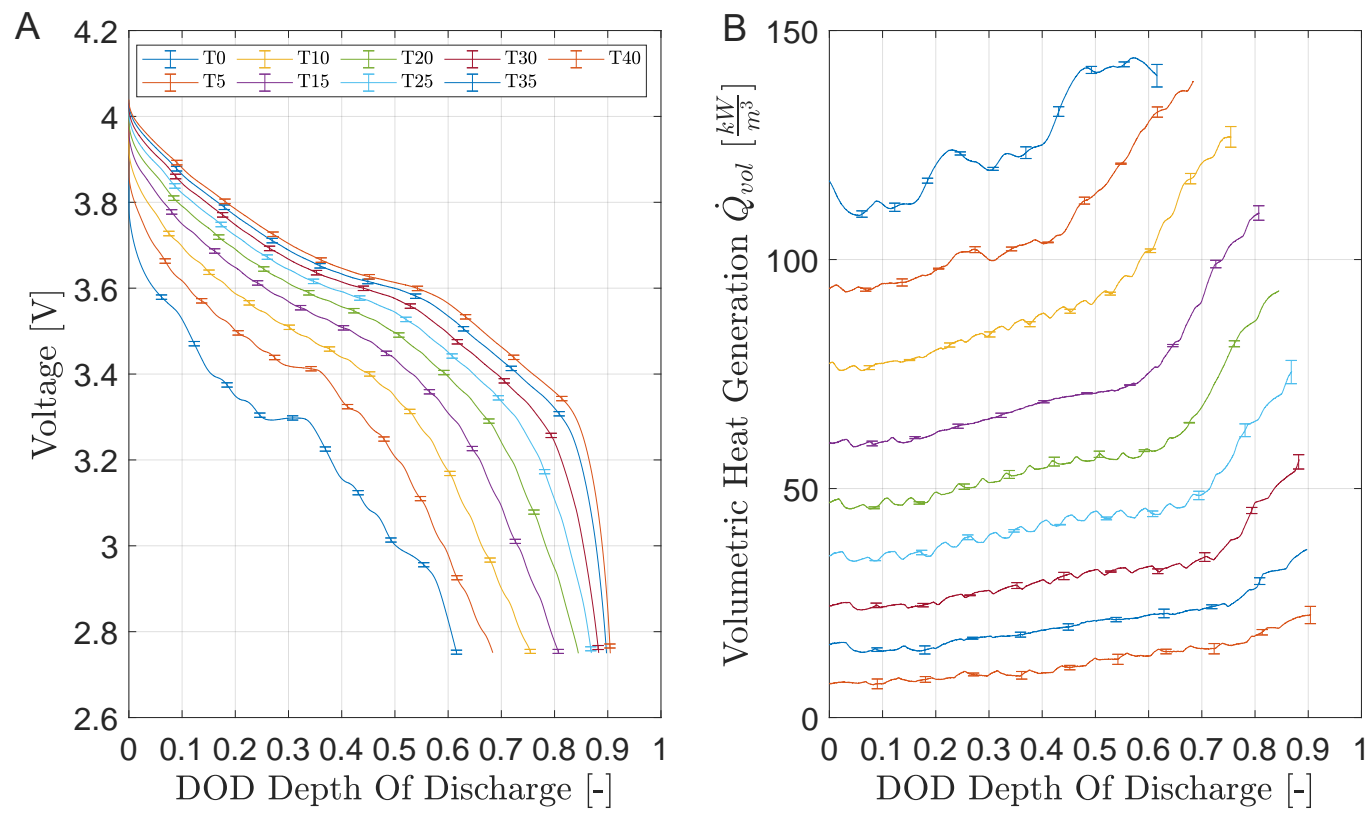

Figure 12: Voltage (A) and volumetric heat generation (B) in function of DOD and average Li-Ion surface temperature $T_{a v}$ at $\mathrm{DR}=1 \mathrm{C}$.

Figure 12 and Figure 13 evaluate the effect of the isothermal conditions imposed to the cell for discharge tests at $\mathrm{DR}=1 \mathrm{C}$. Voltage, volumetric heat generation rate $\dot{Q}_{v o l}$, electrochemical efficiency $\eta$, and heat ratio HR are shown in function of DOD and $T_{\text {set }}$, where DOD is the Depth Of Discharge (DOD), defined as the ratio between the capacity 

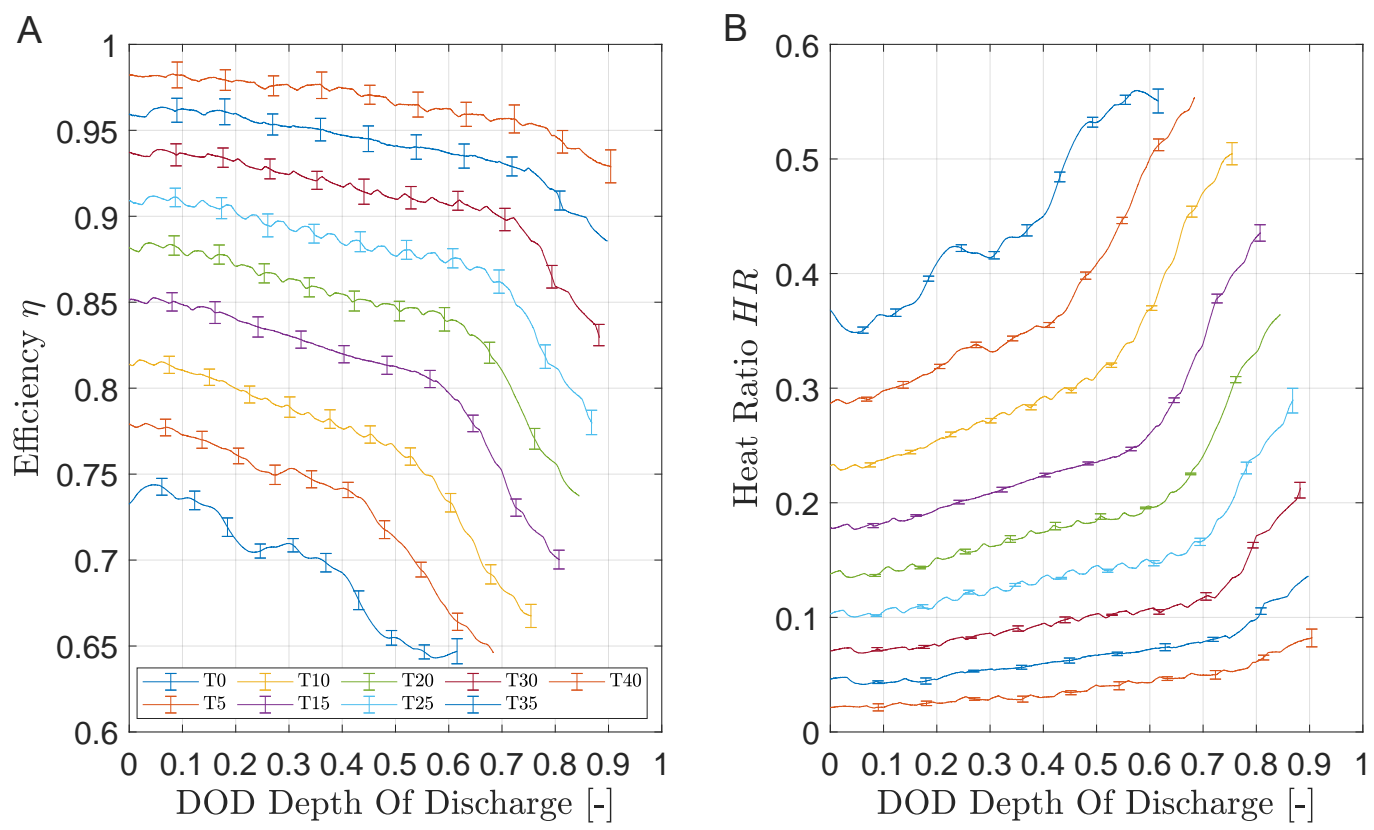

Figure 13: Electrochemical efficiency $\eta(\mathrm{A})$ and HR (B) in function of DOD and average Li-Ion surface temperature $T_{a v}$ at DR=1C.

discharged and the nominal capacity. The DOD can be interpreted as a non-dimensional time. The profiles are composed by data sampled at $1 \mathrm{~Hz}$ and reported without piecewise correction. The uncertainty of the measurements is reported as error bars.

Figure 12 shows that the voltage reaches the safety limit of $2.75 \mathrm{~V}$ faster for lower temperatures. This can be explained by the fact that the cell open circuit voltage increases with temperature while the internal resistance decreases with temperature [42], the latter leading to lower ohmic voltage drops. Being the cell heat generation rate mostly proportional to the heat losses by Joule effect [21] caused by the internal resistance, it is expected to decrease with the temperature, as evident from Figure 12. Accordingly, the electrochemical efficiency and the HR respectively increases and decreases with the temperature.

Figure 14 and Figure 15 evaluate the effect of the DR imposed to the cell by the SMU for discharge tests at average cell surface temperature $T_{a v}=25^{\circ} \mathrm{C}$. Voltage, volumetric heat generation rate $\dot{Q}_{v o l}$, electrochemical efficiency $\eta$, and heat ratio HR are shown in function of DOD and DR. Figure 14 shows that the voltage reaches the safety limit of $2.75 \mathrm{~V}$ faster for higher DRs, leading to final DODs of $87 \%$ at $1 \mathrm{C}$ and $5 \%$ at $5 \mathrm{C}$. This can be explained by the fact that the cell open circuit voltage is independent from the DR while the ohmic irreversible losses increase quadratically with the current and therefore with the DR.

It is worthy to mention that a strong decrease of the discharged capacity with an increasing DR has been observed in previous studies for both cylindrical cells (50\% decrease from DR of 1C to 3C, [43]) and pouch cells (30\% decrease from $\mathrm{DR}$ of $1 \mathrm{C}$ to $5 \mathrm{C},[44])$. However, this phenomena was exacerbated by the proposed test rig as the cell was kept stable at the set temperature and therefore the fictitious gain of capacity by self-heating effect, which is typically experienced in cells tested under stable chamber temperature, was annihilated. 

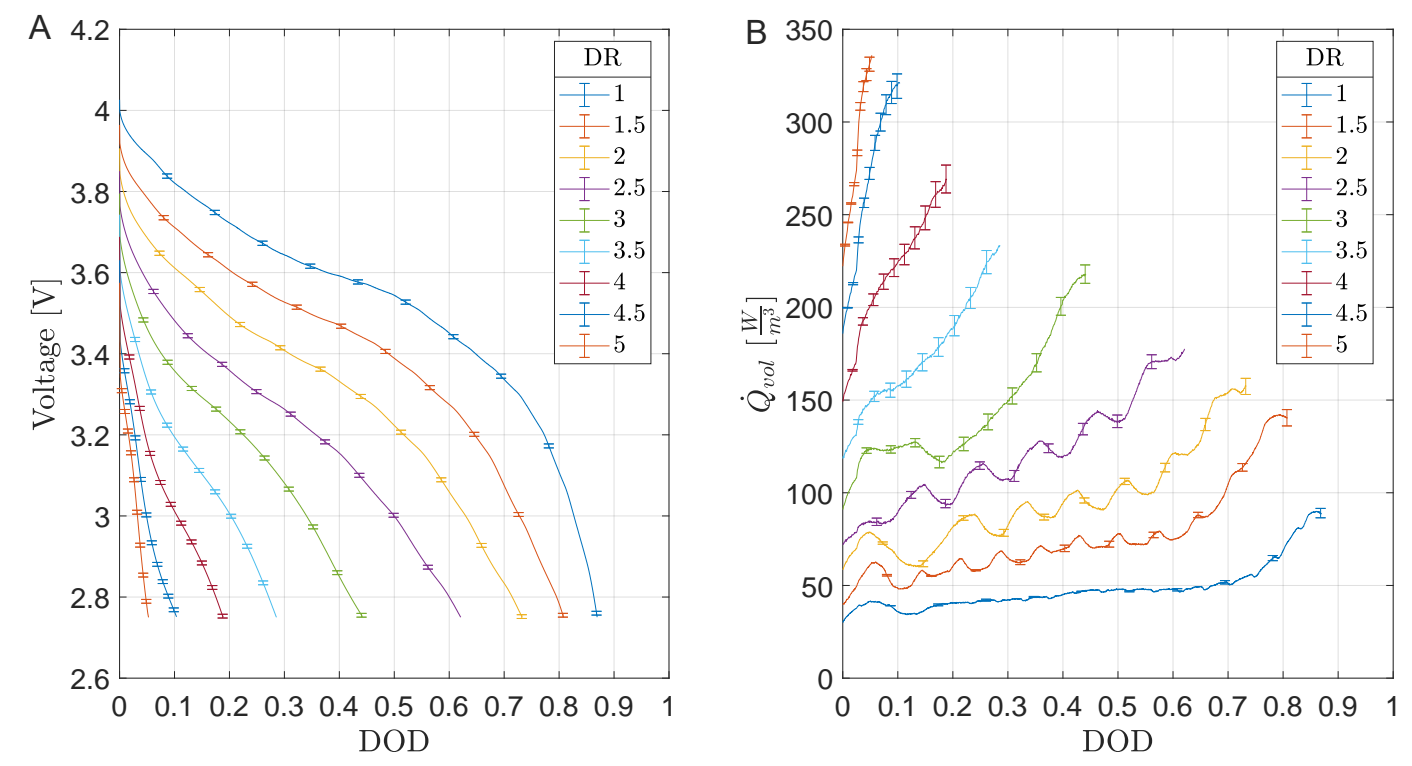

Figure 14: Voltage (A) and volumetric heat generation (B) in function of DOD and DR at average cell surface temperature $T_{a v}=25^{\circ} C$.
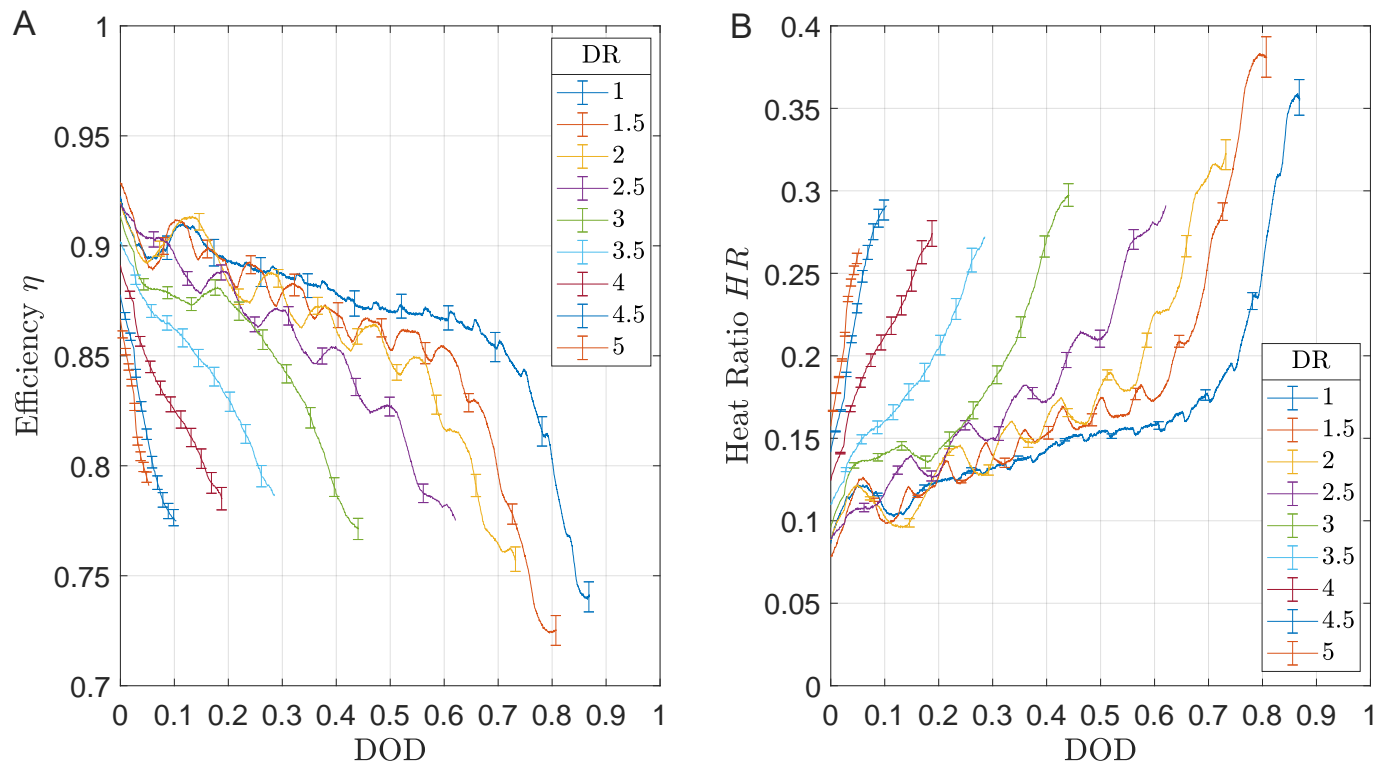

Figure 15: Electrochemical efficiency $\eta(\mathrm{A})$ and HR (B) in function of DOD and DR at average cell surface temperature $T_{a v}=25^{\circ} C$.

Being the cell heat generation rate mostly proportional to the heat losses by ohmic effect $[21,45]$, it is expected to increase with the DR, as evident from Figure 12. Accordingly, the electrochemical efficiency and the HR respectively decreases and increases with the DR.

\subsubsection{Overall performance}

The overall electrical, thermal, and electrochemical performance were evaluated for DR from 1C to 5C step 0.5C and $T_{\text {set }}$ in the range of $0^{\circ} \mathrm{C}-40^{\circ} \mathrm{C}$ with step of $5^{\circ} \mathrm{C}$. All overall quantities reported in the following are based on integral values calculated by integration of the instant properties (e.g. Figure 12 and Figure 13) in function of DOD, as exemplified in Equation 4. The overall results are reported in the supplementary materials [35]. 


\section{Capacity $[\mathrm{Ah}]$}

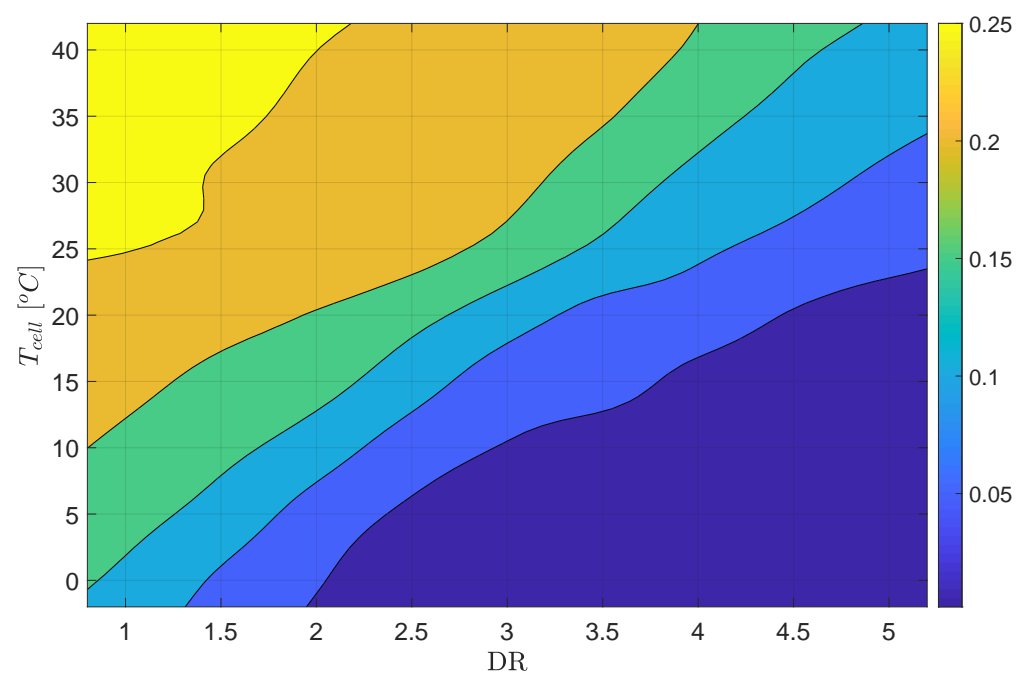

Energy $[\mathrm{Wh}]$

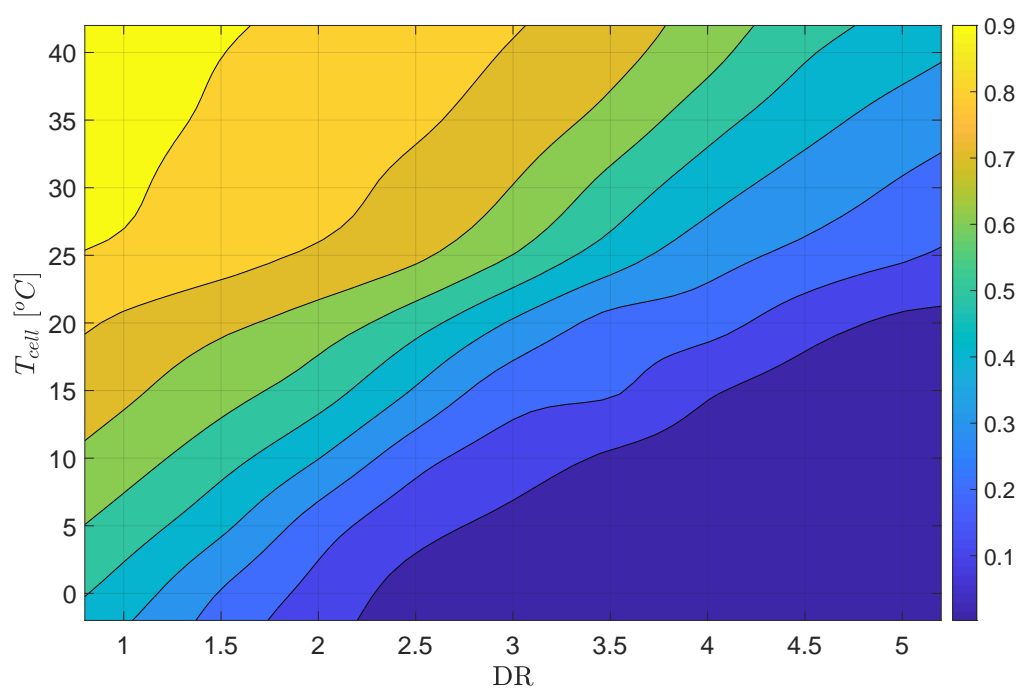

Figure 16: Capacity [Ah] (top) and electrical energy E [Wh] (bottom) for discharge tests at different DR and $T_{\text {set }}$.

The discharged capacity (Figure 16, top) and the electrical energy E (Figure 16, bottom) increase with the cell temperature and decrease with the DR without showing a maximum. Differently, the average electrical power $P_{a v}$ (Figure 17, top) is mainly dependent on the DR; still, it increases appreciably with the cell temperature for high DR.

The average heat generation rate $\dot{Q}_{a v}$ (Figure 17, middle) strongly decreases with the $T_{\text {set }}$ especially at high DR, mainly due to the change of internal resistance (higher at low temperature). The electrochemical efficiency $\eta$ (Figure 17, bottom) follows a similar profile as the capacity and energy, increasing with higher temperatures and lower DR. For instance, the efficiency increases from $75 \%$ to $90 \%$ from $0^{\circ} \mathrm{C}$ to $40^{\circ} \mathrm{C}$. The $\mathrm{DR}$ have a lower influence on the efficiency for higher temperatures. This could be due to a better isothermalisation effect of the TMS. The HR follows a symmetric profile compared to the efficiency, with higher HR for low cell temperatures and high DR. 


\section{Conclusions}

Li-Ion cell performance is sensitive to temperature. Experimental evidence is needed to identify the optimal isothermal condition to be achieved by a Thermal Management System (TMS). Many studies have experimentally investigated the performance of Li-Ion cells under a controlled environmental temperature (i.e. isoperibolic boundary condition); notably however, this condition do not impose a uniform cell surface temperature or a controlled cooling rate, as a TMS would. As it is, the previous literature does not evaluate the sensitivity of the cell overall performance to the cell temperature but to ambient temperature. Most importantly, by not imposing any specific surface heat flux, cells were tested at o perating conditions which strongly differ from the ones imposed by a TMS.

This research study proposes a novel experimental apparatus to replicate a TMS for testing Li-Ion cells under set isothermal conditions. The TMS has two cooling configurations: single-sided and d ouble-sided. Both configurations were tested at discharge rates from $1 \mathrm{C}$ to $5 \mathrm{C}$ and set temperatures from $0^{\circ} \mathrm{C}$ to $40^{\circ} \mathrm{C}$. The double-sided cooling

TMS, having a superior heat transfer coefficient of $128 \frac{W}{m^{2} \kappa}$, guarantees an ideal isothermal condition, i.e. stable cell average surface temperature and temperature disuniformity lower than $5 \mathrm{~K}$, for DRs of up to $2 \mathrm{C}$ and throughout the set temperature range.

Moreover, the proposed apparatus was employed to evaluate electrical, thermal, and electrochemical performance of a commercial Li-ion pouch cell at different DR and isothermal conditions. Results of heat generation rate, electrochemical efficiency, and cell surface temperature disuniformity are presented.

\section{Acknowledgements}

The authors would like to acknowledge Heriot-Watt University to fund this project through the James Watt Scholarship. The authors would like to express their gratitude to Dukosi Ltd. and Mr. Josh Leworthy for providing the cooling chamber and giving support during the development of the test rig.

\section{Data Availability}

Datasets related to this article can be found at http://dx.doi.org/10.17632/fddsp6nnwd.1, an open-source online data repository hosted at Mendeley Data [35]. 
Average Power $P_{a v}[\mathbf{W}]$

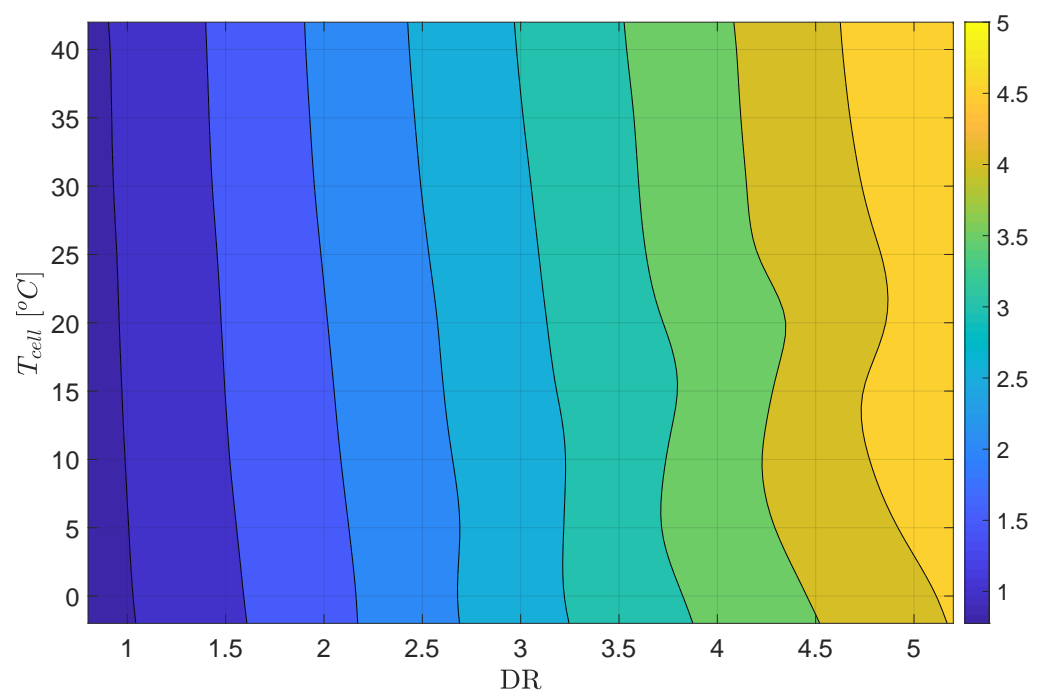

Average Heat Generation Rate $\dot{Q}_{a v}[\mathbf{W}]$

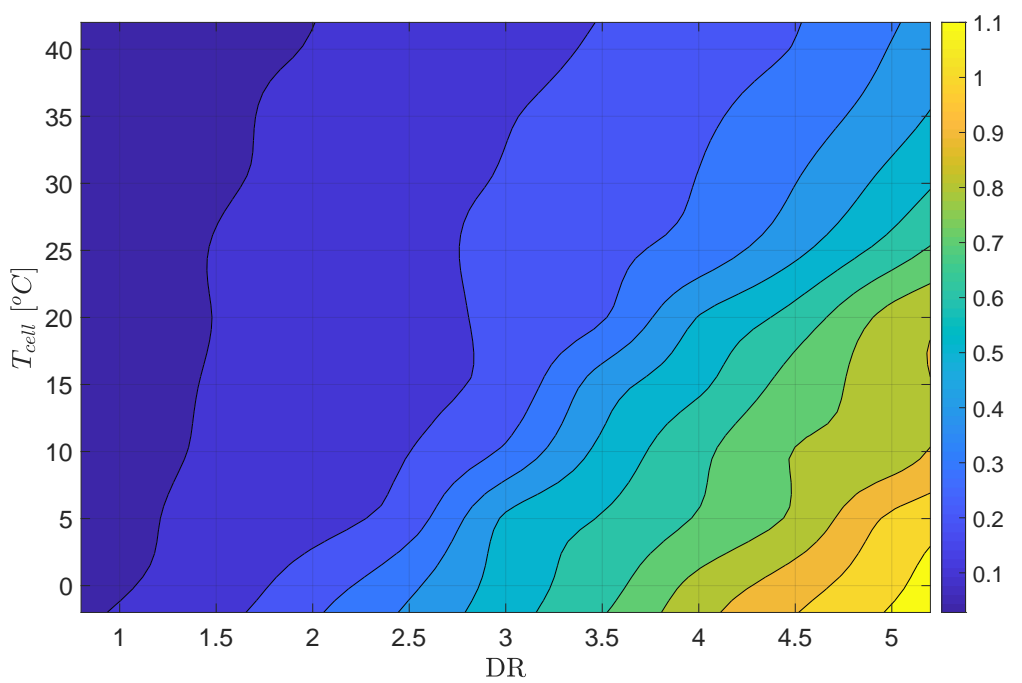

Average Electrochemical Efficiency $\eta$

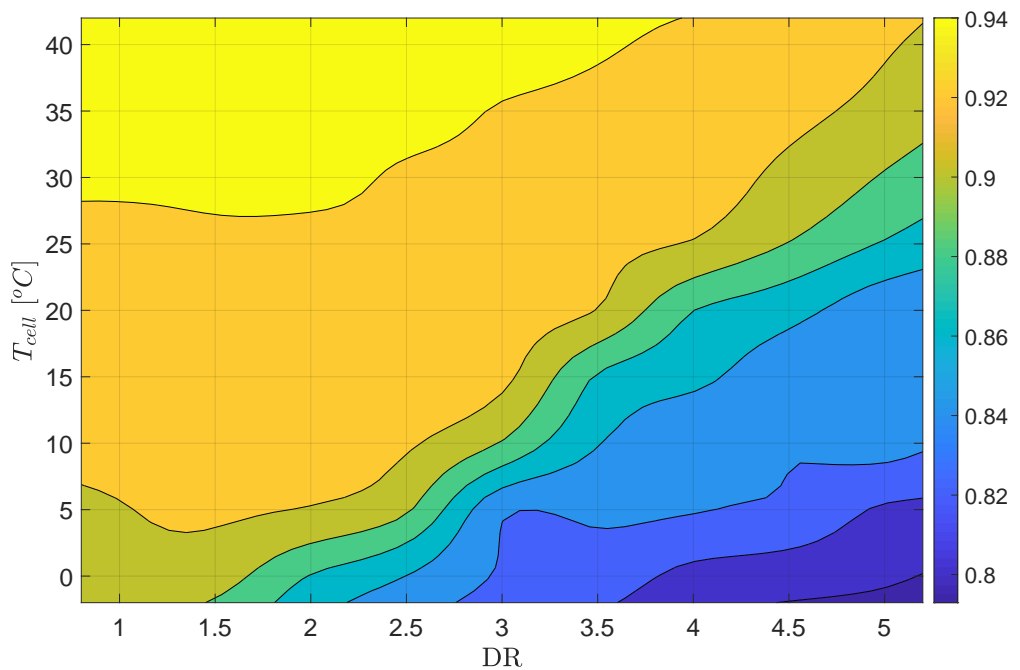

Figure 17: Average Power $P_{a v}[\mathrm{~W}]$ (top), Average Heat Generation Rate [W] (middle), and Electrochemical Efficiency $\eta$ (bottom) for discharge tests at different DR and $T_{\text {set }}$. 


\section{Reference List}

[1] UNFCC, "Paris Agreement - Status of Ratification," 2020.

[2] A. Ghezloun, A. Saidane, and H. Merabet, "The COP 22 New commitments in support of the Paris Agreement," in Energy Procedia, vol. 119. Elsevier Ltd, 2017, pp. 10-16.

[3] UNCTAD, "Renewable Energy Technologies for Rural Development," Tech. Rep., 2010.

[4] NASA, "NASA POWER — Prediction Of Worldwide Energy Resources," 2020.

[5] DTU, "Global Wind Atlas," 2020.

[6] International Energy Agency, "Technology Roadmap Energy storage," Tech. Rep., 2014.

[7] REN21, "RENEWABLES 2017 GLOBAL STATUS REPORT," Tech. Rep., 2017.

[8] REN21, "Renewables 2019: Global Status Report," Tech. Rep., 2019.

[9] International Energy Agency, "Tracking Clean Energy Progress 2017 Informing Energy Sector Transformations," Tech. Rep., 2017.

[10] S. Landini, J. Leworthy, T. O’Donovan, and T. O’Donovan, "A Review of Phase Change Materials for the Thermal Management and Isothermalisation of Lithium-Ion Cells," Journal of Energy Storage, vol. 25, no. February, p. 100887, 2019.

[11] B. Shabani and M. Biju, "Theoretical modelling methods for thermal management of batteries," Energies, vol. 8, no. 9, pp. $10153-10177,2015$.

[12] Z. Rao and S. Wang, "A review of power battery thermal energy management," Renewable and Sustainable Energy Reviews, vol. 15, pp. 4554-4571, 2011.

[13] S. Panchal, K. Gudlanarva, M.-k. Tran, and R. Fraser, "High Reynold's Number Turbulent Model for MicroChannel Cold Plate Using Reverse Engineering Approach for Water-Cooled Battery in Electric Vehicles," Energies, vol. 13, p. 1638, 2020.

[14] S. Panchal, S. Mathewson, R. Fraser, R. Culham, and M. Fowler, "Measurement of Temperature Gradient (dT/dy) and Temperature Response (dT/dt) of a Prismatic Lithium-Ion Pouch Cell with LiFePO4 Cathode Material," SAE Technical Papers, vol. 2017-March, no. March, 2017.

[15] M. S. Patil, J. H. Seo, S. Panchal, S. W. Jee, and M. Y. Lee, "Investigation on thermal performance of water-cooled Li-ion pouch cell and pack at high discharge rate with U-turn type microchannel cold plate," International Journal of Heat and Mass Transfer, vol. 155, p. 119728, 2020.

[16] S. Landini, R. Waser, A. Stamatiou, R. Ravotti, J. Worlitschek, and T. O'Donovan, "Passive cooling of Li-Ion cells with direct-metal-laser-sintered aluminium heat exchangers filled with phase change materials," Applied Thermal Engineering, vol. 173, no. February, p. 115238, 2020. 
[17] J. S. Hong, H. Maleki, S. Al Hallaj, L. Redey, and J. R. Selman, "Electrochemical-calorimetric studies of lithium-ion cells," Journal of the Electrochemical Society, vol. 145, no. 5, pp. 1489-1501, 1998.

[18] S. Al Hallaj, J. Prakash, and J. R. Selman, "Characterization of commercial Li-ion batteries using electrochemicalcalorimetric measurements," Tech. Rep., 2000.

[19] L. H. Saw, Y. Ye, and A. A. Tay, "Electrochemical-thermal analysis of 18650 Lithium Iron Phosphate cell," Energy Conversion and Management, vol. 75, pp. 162-174, 2013.

[20] J. Seo, S. Sankarasubramanian, C. S. Kim, P. Hovington, J. Prakash, and K. Zaghib, "Thermal characterization of $\mathrm{Li} /$ sulfur, $\mathrm{Li} / \mathrm{S}-\mathrm{LiFePO} 4$ and $\mathrm{Li} / \mathrm{S}-\mathrm{LiV} 3 \mathrm{O} 8$ cells using isothermal Micro-Calorimetry and accelerating rate calorimetry," Journal of Power Sources, vol. 289, pp. 1-7, 2015.

[21] S. Panchal, I. Dincer, M. Agelin-Chaab, R. Fraser, and M. Fowler, "Experimental and simulated temperature variations in a LiFePO4 - 20 Ah battery during discharge process," Applied Energy, vol. 180, pp. 504-515, 2016.

[22] K. Chen, G. Unsworth, and X. Li, "Measurements of heat generation in prismatic Li-ion batteries," Journal of Power Sources, vol. 261, pp. 28-37, 2014.

[23] M. Malik, I. Dincer, M. A. Rosen, M. Mathew, and M. Fowler, "Thermal and electrical performance evaluations of series connected Li-ion batteries in a pack with liquid cooling," Applied Thermal Engineering, vol. 129, pp. 472-481, 2018.

[24] F. He, H. Wang, and L. Ma, "Experimental demonstration of active thermal control of a battery module consisting of multiple Li-ion cells," International Journal of Heat and Mass Transfer, vol. 91, pp. 630-639, 2015.

[25] S. J. Drake, M. Martin, D. A. Wetz, J. K. Ostanek, S. P. Miller, J. M. Heinzel, and A. Jain, "Heat generation rate measurement in a Li-ion cell at large C-rates through temperature and heat flux measurements," Journal of Power Sources, vol. 285, pp. 266-273, 2015.

[26] C. Lin, S. Xu, Z. Li, B. Li, G. Chang, and J. Liu, "Thermal analysis of large-capacity LiFePO 4 power batteries for electric vehicles," Journal of Power Sources, vol. 294, pp. 633-642, 2015.

[27] M. R. Giuliano, A. K. Prasad, and S. G. Advani, "Experimental study of an air-cooled thermal management system for high capacity lithium-titanate batteries," Journal of Power Sources, vol. 216, pp. 345-352, 2012.

[28] C. Zhao, W. Cao, T. Dong, and F. Jiang, "Thermal behavior study of discharging/charging cylindrical lithiumion battery module cooled by channeled liquid flow," International Journal of Heat and Mass Transfer, vol. 120, pp. 751-762, 2018.

[29] R. Kizilel, A. Lateef, R. Sabbah, M. M. Farid, J. R. Selman, and S. Al-Hallaj, "Passive control of temperature excursion and uniformity in high-energy Li-ion battery packs at high current and ambient temperature," Journal of Power Sources, vol. 183, pp. 370-375, 2008.

[30] Reichelt Elektronik, "AKKU IPD NANO 1G: Datasheet," 2020. 
[31] EUCAR, "Battery requirements for future automotive applications EG BEV\&FCEV," Tech. Rep., 2019.

[32] L. Michalski, K. Eckersdorf, J. Kucharski, and J. McGhee, "Temperature Measurement, 2nd edn," Measurement Science and Technology, vol. 13, no. 10, pp. 1651-1652, oct 2002.

[33] J. S. Bendat and A. G. Piersol, "Random Data Analysis and Measurement Procedures," Measurement Science and Technology, vol. 11, no. 12, p. 1825, 2000.

[34] T. L. Bergman, A. S. Lavine, F. P. Incropera, and D. P. Dewitt, Fundamentals of Heat and Mass Transfer. USA: John Wiley \& Sons, Inc., 2011.

[35] [dataset] S. Landini and T. S. O'Donovan, "Novel experimental approach for the characterisation of Lithium-Ion cells performance in isothermal conditions: Datasets and Supplementary Materials," 2020, Mendeley Data, v1. [Online]. Available: http://dx.doi.org/10.17632/fddsp6nnwd.1

[36] D.-I. Stroe, M. Swierczynski, A.-I. Stroe, and S. Knudsen Kær, "Generalized Characterization Methodology for Performance Modelling of Lithium-Ion Batteries," Batteries, vol. 2, no. 4, p. 37, 2016.

[37] X. Wu, W. Shi, and J. Du, "Multi-objective optimal charging method for lithium-ion batteries," Energies, vol. 10, no. 9, pp. 1-18, 2017.

[38] R. Zhao, S. Zhang, J. Liu, and J. Gu, "A review of thermal performance improving methods of lithium ion battery: Electrode modification and thermal management system," Journal of Power Sources, vol. 299, pp. $557-577,2015$.

[39] S. Shahid and M. Agelin-Chaab, "Analysis of cooling effectiveness and temperature uniformity in a battery pack for cylindrical batteries," Energies, vol. 10, no. 8, 2017.

[40] J. H. I. Lienhard and J. H. V. Lienhard, A Heat Transfer Textbook, 4th ed. Massachusetts, U.S.A: Phlogiston Press Cambridge, 2017.

[41] S. V. Patankar, Numerical heat transfer and fluid flow. Hemisphere, 1980.

[42] Y. Lai, S. Du, L. Ai, L. Ai, Y. Cheng, Y. Tang, and M. Jia, "Insight into heat generation of lithium ion batteries based on the electrochemical-thermal model at high discharge rates," International Journal of Hydrogen Energy, vol. 40, pp. $13039-13049,2015$.

[43] G. Ning, B. Haran, and B. N. Popov, "Capacity fade study of lithium-ion batteries cycled at high discharge rates," Journal of Power Sources, vol. 117, no. 1-2, pp. 160-169, may 2003.

[44] J. Shim and K. A. Striebel, "Cycling performance of low-cost lithium ion batteries with natural graphite and LiFePO 4," Journal of Power Sources, vol. 119, pp. 955-958, 2003.

[45] N. Javani, I. Dincer, G. F. Naterer, and G. L. Rohrauer, "Modeling of passive thermal management for electric vehicle battery packs with PCM between cells," Applied Thermal Engineering, vol. 73, pp. 307-316, 2014. 